\title{
The local and foreign influences on religious architecture in Aleppo during the Ottoman period 922-1366 A.H/ 1516-1918 A.D
}

\author{
Mansour Abd al-Razik \\ Associate prof. at faculty of archaeology, Islamic archaeology department, \\ Cairo University \\ mansour.arch@cu.edu.eg
}

\begin{abstract}
This paper aims to study the local influences that characterized the characteristics of religious architecture in Aleppo before the Ottoman era and positively affected it during the Ottoman period. The paper aims also to study the foreign influences on these buildings, whether those that appeared in conjunction with the foreign Ottoman style or those that came from other countries of the Islamic world, settled in the city of Aleppo, and continued during the Ottoman period. The paper studies these influences on the religious architecture in Aleppo during the Ottoman period through following its plans and its architectural elements to show the effect of the local and foreign influences on it and show the plans and the architectural elements that gathered between the two influences. Moreover, the paper sheds light on local influences in the field of the architectural treatments used by the architect during the Ottoman period.
\end{abstract}

Keywords: Aleppo, Ottoman, local, foreign, influences, religious, plans, elements

\section{Introduction:}

The Ottoman state is considered one of the most important states that controlled during its flourished in many parts of the Islamic world, it began as a small border province in the west of Anatolia or minor Asia in 699 A.H/ 1299 A.D (al-Haddad, 2014). After a short time, this province grew, expanded, became a large Islamic state, and rightly deserved to be called by the historian as an empire, especially after it controlled many provinces that spread in the three-continent Asia, Africa, and Europe (al-Shinnawy, 1980).

Syria or the Levant, in general, was subjected to Ottoman control after the conflict that began between the Ottoman and Mamluk states as a result of conflicting common interests between them. The battle of Marj Dabiq in 922 A.H/ 1516 A.D was the first friction event that occurred between the two states (Ibn Iyas, 1982). During the events of this battle, the Ottoman state under the leader of Sultan Selim I defeated the Mamluk troops under the leader of Sultan al-Ghuri, and this Ottoman victory represent the first point to control on all Mamluk lands.

Aleppo was the first Syrian city that fell under Ottoman control (Raymond, 1985) perhaps for the proximity of its location to the site of the aforementioned battle. Although the civilizational delay of many provinces that were fell under Ottoman control, the city of Aleppo flourished during this period, especially for the first century of the Ottoman occupation (Raymond, 1998). Moreover, some historians considered it the actual capital of Syria during this period (Russell, 1794) and some of them considered it also the third 
important city in the Ottoman empire after Istanbul and Cairo (Gaube \& Wirth, 1984). The prosperity of Aleppo was related to the fact that it was no longer a border city as it was before, but rather became the center of the Ottoman Empire (David \& Heretani, 2011). Also, it clearly benefited from its openness to most of its affiliated states and became one of the most important major commercial centers in the region (al-Afandi 2017).

Because of this prosperity in the city of Aleppo during this period, the architectural activities flourished, and new styles of religious architectural buildings appeared (Zein al-'abidin, 2010). The city of Aleppo was one of the most provinces of the Ottoman Empire, in which the new Ottoman style became widespread, more than other provinces that may be more famous than the city of Aleppo itself such as Damascus and Cairo (David \& Heretani, 2011). In Damascus, the examples of buildings that were built according to the Ottoman style were limited and were inferior to those in Aleppo with the exception of al-sulimaniyyah teykia 962 A.H/ 1555 A.D (Wolsinger \& Watsinger, 1984). This applied also to Cairo in that the foreign Ottoman style could not compete with the inherited local style which was rooted with the Egyptian architect over many centuries (al-Haddad, 1998).

There are many reasons for the spread of the foreign Ottoman style in religious architecture in Aleppo, more than many provinces that were submitted to the Ottoman authority. The most important reason was the geographical proximity between Aleppo and the Turkish capital Istanbul, which strengthens the factors of influence between the two cities. Among these also, the close relationship that was connected between the majority of the city's deputies and the central authority as most of them were those who occupied high positions in the capital Istanbul. Moreover, the economic importance of the city of Aleppo during the Ottoman period, especially in the $10^{\text {th }}$ A.H/ $16^{\text {th }}$ A.D century (David \& Heretani, 2011).

Although the preceding, this is not mean that the local styles that spread in religious architecture in Aleppo before the Ottoman period disappeared, but it continued and strongly affected the architecture of this period. This is what is accustomed in the provinces that fell under the Ottoman control so that some buildings were built according to the new Ottoman style while the majority of them are a reflection and a continuation of the inherited local styles. The gathering between the local styles and the Ottoman influences can be found in the majority of the countries or the provinces that fell under the Ottoman rule such as Egypt (al-Haddad, 1998), Yemen, which strongly affected by the Ottoman influences (Enab, 2019), Algeria (Billah, 2008) and Tunis (Fekry, 1949) in addition to Syria which the paper allocated to study the case of one of its cities.

If we apply this regard to the religious architecture in Aleppo during the Ottoman period, we find that the outstanding examples of these buildings were built according to the foreign Ottoman style. At the same time, the local styles are used on the rest of these buildings, which represent the largest number of the buildings of this period. Moreover, we cannot neglect the effect of the local styles on the buildings that were built according to the Ottoman style itself. 
For the preceding, the paper aims to follow the local and the foreign influences on the religious architecture of Aleppo during the Ottoman period through following the plans of these buildings to show the foreign example of which, the plans that consider a continuation to the local styles, and the effect of the foreign style on the local plans. The paper also follows the architectural elements of these buildings to show the limit of the continuation of the local styles and the effect of the foreign elements on these buildings.

\section{Plans of the religious buildings in Aleppo during the Ottoman period:}

The plans of the religious buildings that were constructed in Aleppo during the Ottoman period varied in many styles according to the various influences (Table 1). The first one, those buildings that were constructed according to the foreign Ottoman Turkish style. The second style, the buildings that followed the inherited local plans, which were used in the city during the Ayyubid and Mamluk periods. Finally, there are the buildings that followed the inherited local styles with some influences from the Ottoman style, which means that those plans gathered between the foreign and the local styles (Table 1).

\subsection{The foreign Ottoman plan:}

After the city of Aleppo fell under the Ottoman sultanate in 922 A.H/ 1516 A.D, a new style of its religious buildings appeared. This style of buildings spread in the city especially during the $10^{\text {th }}$ A.H/ $16^{\text {th }}$ A.D century, it is completely different from the old styles that were commonly used before the Ottoman period (Kafescioğlo, 1999). These buildings characterize with hugeness in their architecture if we comparing them with those that were built according to the local style (Raymond, 1979).

The square shape is customarily used in the sanctuary which is locally called alqibliyyah. The sanctuary characterizes by the vastness of its inner space which extends with no barriers as common in the Turkish mosques (Freely, 2011). The huge domes are roofing this vast space of al-qibliyyah and the architect excelled in resting these domes on the sidewalls with no barriers that obstructed the view inside them. The examples of these domes are distinguished by their tremendous heights that contribute to increasing the inner spaces, and are similar to each other in covering with lead tiles that reflect the sun's rays in an attractive view, so that who coming to the city can distinguish the building of this style in all districts in which they spread.

Besides these, this style of buildings includes an aisle that extends horizontally in front of the sanctuary so that its extension increases to the right and left sides than the extension of the sanctuary (Othman, 1992). The small and shallow domes are used in roofing this aisle except for some examples that are influenced by the local styles which are roofed by cross vaults. On the middle of this aisle, there is the entrance of the sanctuary, which the architect magnified in caring it to the extent that it became much precise and more decorated in some examples than the main entrance. In the right side of the aisle, the minaret rises according to the Ottoman Turkish style. The buildings of the Ottoman style include also a garden located behind the sanctuary. This plan was derived from the Ottoman mosques of the Turkish cities such as the mosque of Davud pasha in 
Istanbul 890 A.H/ 1485 A.D (fig. 1), and the mosque of Atiq Ali pasha in Istanbul 903 A.H/ 1497 A.D (fig. 2) (Goodwin, 2003).

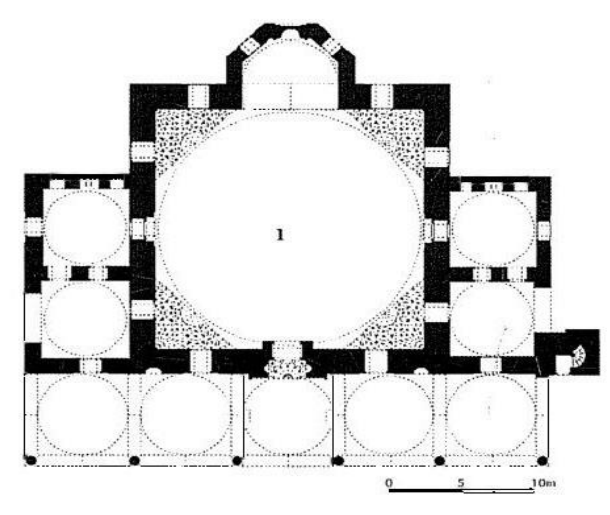

Fig. 1: Plan of Davud pasha mosque in Istanbul 890 A.H/ 1485 A.D. Goodwin, 2003, fig. 107.

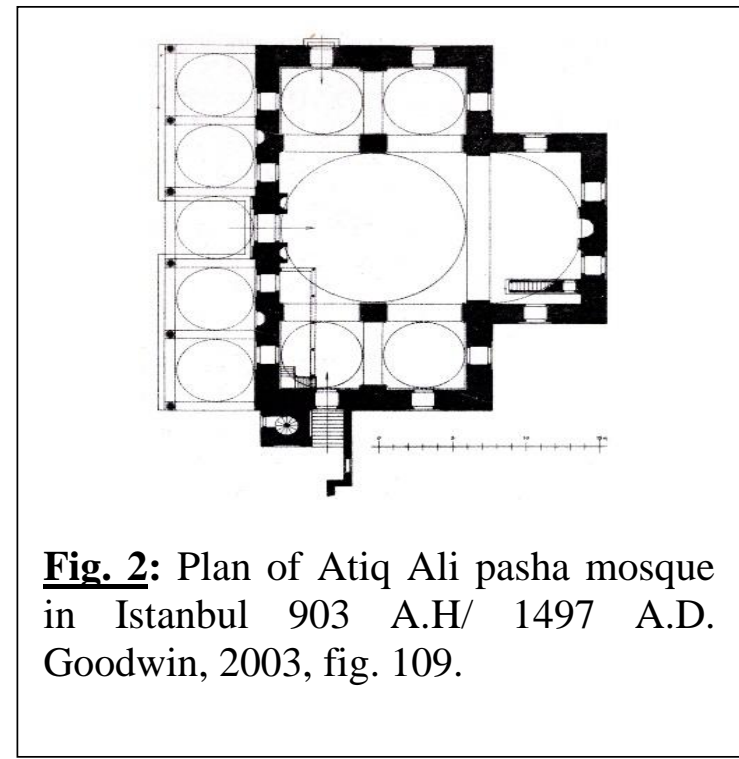

The most important examples of the buildings that were constructed according to the foreign Ottoman style in Aleppo; the mosque and madrasa of al-Khusrawiyyah 951 A.H/ 1544 A.D $^{(1)}$ (fig. 3). It is the first building that was constructed by the famous architect Sinan (David \& Heretani, 2011), which represents a great effect in the tremendous development of the architectural activity in the city of Aleppo. The mosque includes a square sanctuary roofed by a huge dome, a horizontal aisle roofed by shallow domes fronts the sanctuary. The aisle includes the minaret of the mosque on the Ottoman style on its right side, it also includes the entrance of the sanctuary in the middle of its southern wall according to the entrances of the Ottoman mosques (Talas, 1956).

Among the buildings that were constructed according to the Ottoman style, the mosque of al- 'Adiliyyah 963 A.H/ 1555 A.D ${ }^{(2)}$ (fig. 4), which consider a repeat copy of the Mosque of al-Khusrawiyyah. It includes a square sanctuary roofed by a huge dome, an aisle fronted the sanctuary and an Ottoman minaret.

There is also, the mosque of Bahram pasha 991 A.H/ 1583 A.D ${ }^{(3)}$ (fig. 5), which is considered one of the most important buildings that were constructed according to the foreign Ottoman style. Its plan is similar to the plan of al-Khusrawiyyah and al- Adilyyah except for the dome of the sanctuary which rests on four pillars instead of the sidewalls in the aforementioned examples ${ }^{(4)}$. Also, the architect allocates a separate iwan for the mihrab.

The new foreign Ottoman style was subjected to a noticeable decline during the $11^{\text {th }}$ A.H/ $17^{\text {th }}$ A.D century to the extent that the mosque of the biggest architectural complex was built according to the inherited local styles ${ }^{(5)}$. The Ottoman-style was revived again during the $12^{\text {th }}$ A.H/ $18^{\text {th }}$ A.D century in al-Othmaniyyah madrasa that was constructed in 1141 A.H/ 1730 A.D ${ }^{(6)}$ (fig. 6), where its plan was derived from the Ottoman style. 

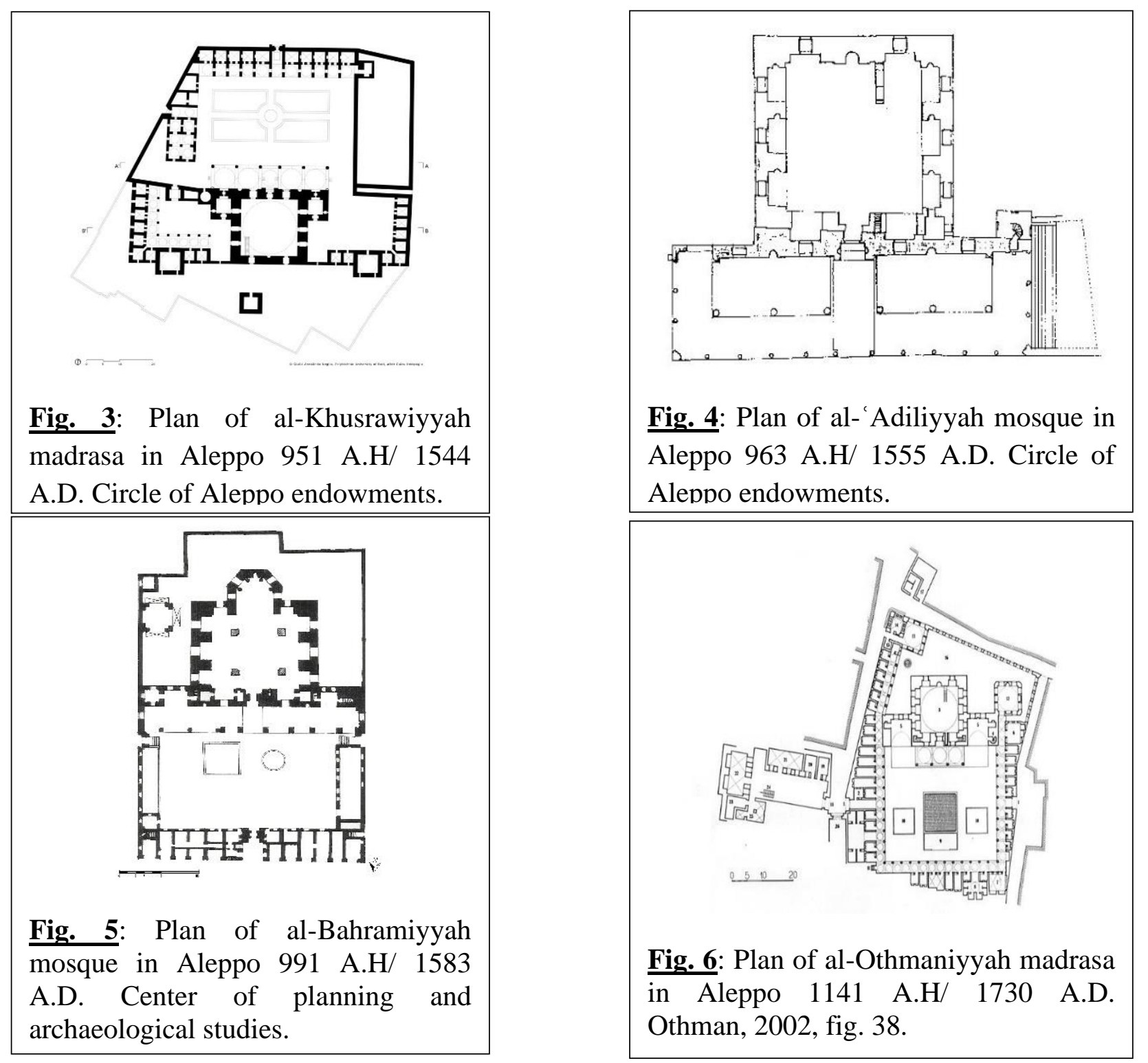

All previous examples were also constructed according to the architectural complex system that each includes various buildings for various functions. AlBahramiyyah mosque 991 A.H/ 1583 A.D as an example; includes a congregational mosque for prayers, a madrasa for teaching, residence rooms for students, a turbah for burial, garden, sabil, and souk. Gathering among these various units in one building reflect the system of the architectural complex which reflect an influence that came from the east of Islamic world as the first example of the architectural complex appeared in the complex of Gohar Nusseibeh in Kayseri 602 A.H/ 1205 A.D. After that the system of the architectural complex spread in the eastern cities and moved to Egypt during the Bahri Mamluk rule in the complex of al-Mansour Qalawun 683-684 A.H/ 1284-1285 A.D, and then spread in the majority of the cities of the Islamic world. 
The new Ottoman style did not limit to the religious buildings of the great waqfs in Aleppo as aforementioned, but many small mosques and madrasas were constructed according to this style. Among these examples; the mosque and zawiya of Abi al-Darajin 950 A.H/ 1544 A.D ${ }^{(7)}$, which composes of a square sanctuary according to the Ottoman style, so that it is considered the first monument constructed according to this foreign style. Among these also, the mosque of al-Hamawy 968 A.H/ $1561^{(8)}$, and the mosque of Khan al-Jumruk 982 A.H/ 1575 A.D which was constructed on a unique style came to Aleppo during this period on a ribbed plan with hexagon shape (fig. 7). The ribbed plan previously appeared in the Ottoman architecture such as the plan of Kapi Ağasi madrasa in Amasya 893 A.H/ 1488 A.D (fig. 8), and Rustum Pasha madrasa in Istanbul 957 A.H/ 1550 A.D.
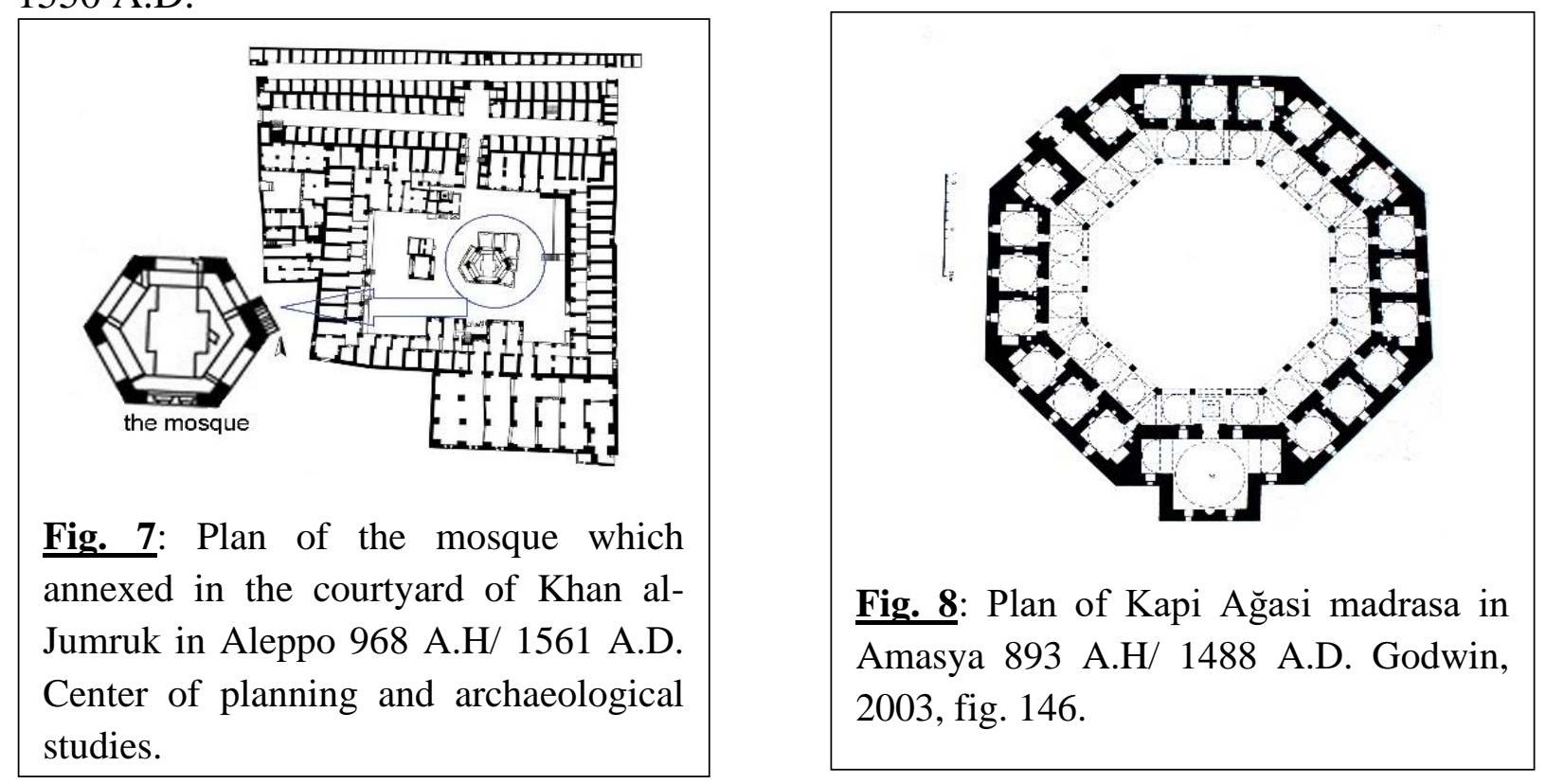

The conclusion which can be drawn of the preceding, the Ottoman style affected the religious architecture after the city of Aleppo fell under the Ottoman sultanate to the extent that the most famous examples of these buildings were constructed according to this style especially during the $10^{\text {th }}$ A.H/ $16^{\text {th }}$ A.D century. After that, this style declined during the $11^{\text {th }}$ A.H/ $17^{\text {th }}$ A.D century and revived again during the $12^{\text {th }}$ A.H/ $18^{\text {th }}$ A.D century.

\subsection{The local plan:}

The local plans are considered the most widespread in the religious architecture in Aleppo during the Ottoman period, those plans that are considered a continuation of the style of the buildings of the Ayyubid and Mamluk periods. This inherited local style was used in the largest number of the religious buildings of the city during this period which strongly asserts the influence of these inherited styles and thier continuation during the Ottoman period ${ }^{(9)}$.

The local plan which used in these buildings composes of a rectangular sanctuary that extends from east to west, the inner area of the sanctuary is divided into three parts; the middle one in front of the mihrab roofed by a dome, while the other two areas are 
roofed by a pointed or across vault. Sometimes, the inner area of the sanctuary was divided into small square areas roofed by cross vaults. In this plan, the sanctuary is directly fronted by an open courtyard surrounded on its other three sides by porticos or extensions such as the ablution room, the Imam room, the student's cells in case of the madrasas, and in most cases the eastern side occupied by an iwan or portico that is locally called al-Hijazyyah. This is the plan that has commonly been used in the religious architecture in the city of Aleppo since the earlier periods, as we can find it with minor differences in the great Umayyad mosque 96 A.H/ 717 A.D (fig. 9). It spread also during the Ayyubid period such as al-Shazbakhtiyyah madrasa 589 A.H/ 1193 A.D, alSultaniyyah madrasa 620 A.H/ 1223 A.D (fig. 10). the same plan continued also during the Mamluk period such as Ashiqtumur mosque 773 A.H/ 1372A.D (fig. 11), and the mosque of Othman Ibn Oghilbik 881 A.H/ 1477 A.D (fig. 12).

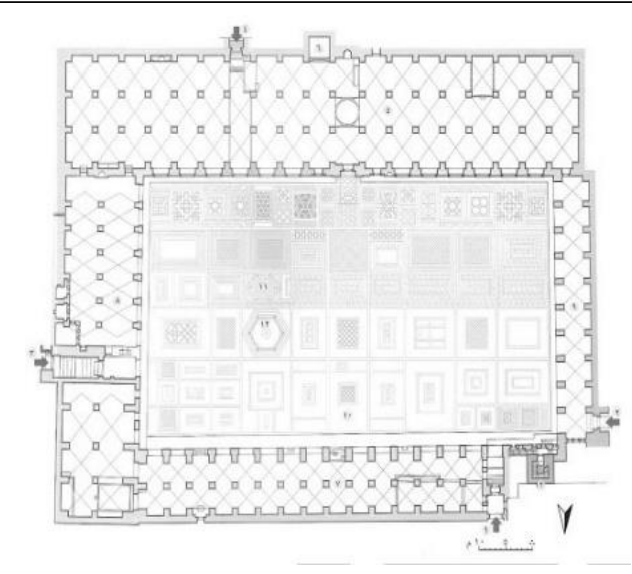

Fig. 9: Plan of the great Umayyad mosque in Aleppo 96 A.H/ 717 A.D. Circle of Aleppo indowments.

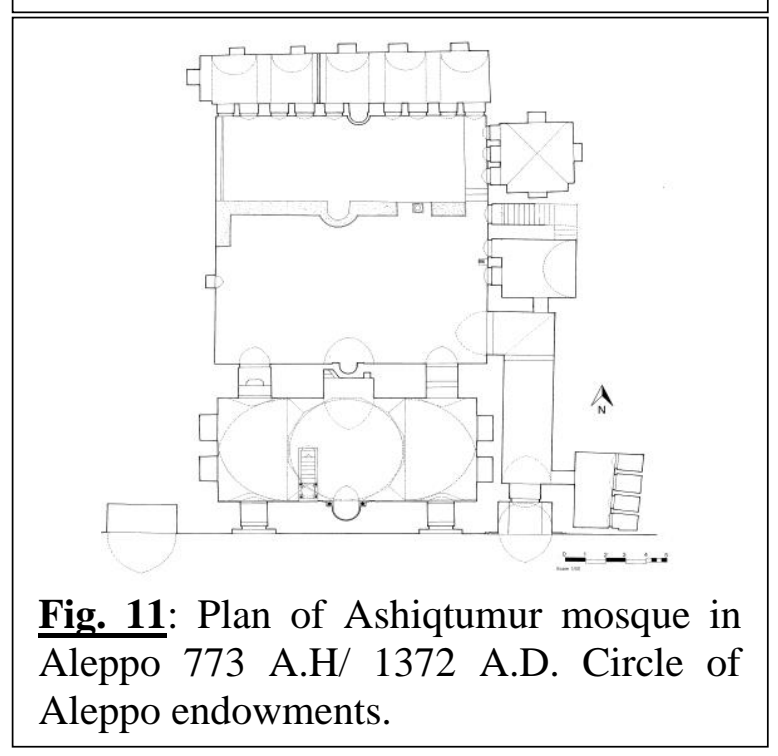

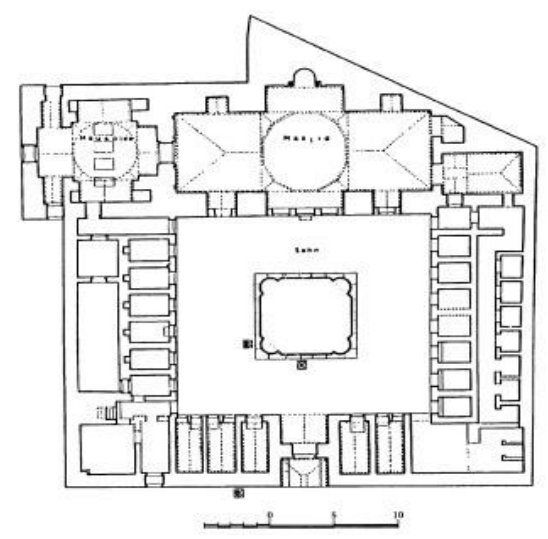

Fig. 10: Plan of al-Sultaniyyah madrasa in Aleppo 620 A.H/ 1223 A.D. Tabaa, 1993, fig. 4.

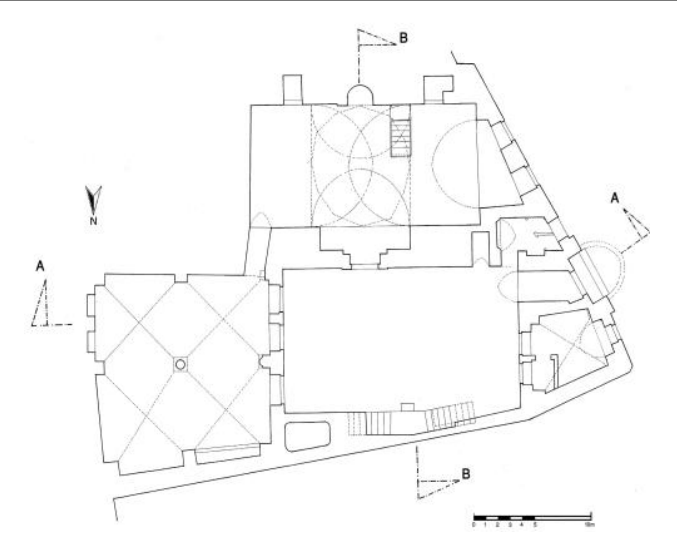

Fig. 12: Plan of Othman Ibn Oghelbek mosque in Aleppo 881 A.H/ 1477 A.D. Center of planning and archaeological studies. 
This local plan continued also after the city fell under the Ottoman sultanate. The most famous example of religious architecture that was constructed according to the local plan during the Ottoman period, the mosque of Ibshir pasha in al-jadidah district which included among the most famous waqf in the city during the $11^{\text {th }}$ A.H/ $17^{\text {th }}$ A.D century (David \& Heretani, 1982). The mosque composes of a rectangular sanctuary divided into three areas; the middle one in front of the mihrab roofed by a dome, and the two other areas in the east and the west sides roofed by cross vaults. Beside the sanctuary from the north side, there is the courtyard connects with the sanctuary by three arched-opens (fig 13).

This plan applies to many examples of religious architecture in the city during the Ottoman period such as al-Sha banyyah madrasa in al-Farafrah district 1085 A.H/ 1674 A.D (al-Jasir, 2000) (fig. 14), and the mosque of al-Mashatiyyah 1131 A.H/ 1718 A.D (al-Ghuzzi, 1999).

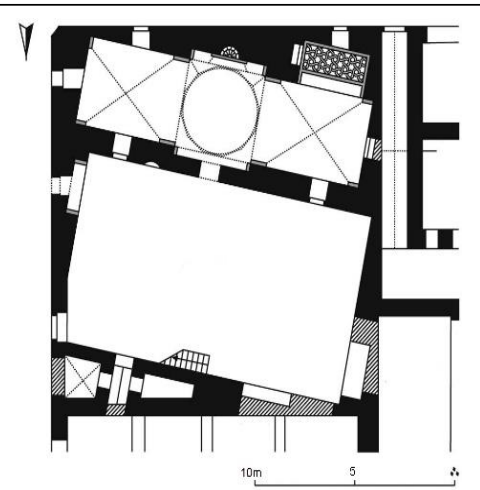

Fig. 13: Plan of Ibshir pasha mosque in Aleppo 1063 A.H/ 1652 A.D. David, 1982, fig. 21.

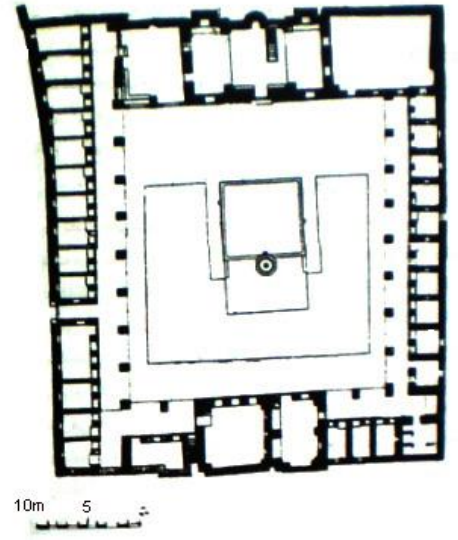

Fig. 14: Plan of al-Sha'baniyyah madrasa in Aleppo 1086 A.H/ 1674 A.D. al-Jasir, 2000, fig. 103.

\subsection{The local plan that influenced by the foreign Ottoman plan:}

Among the plans of the religious architecture of Aleppo during the Ottoman period, those buildings that constructed according to the inherited local plan with some influences of the foreign Ottoman plan. The sanctuary of these buildings follows the local plan. At the same time, it is fronted by an aisle or portico ${ }^{(10)}$ roofed by shallow domes, which is considered a foreign influence on this local plan. From the preceding, we can assert that these buildings gathered between the local and the foreign styles in one plan.

Besides these, there is the back garden behind and around the sanctuary, which is considered also an influence from the Ottoman style on the local plan. This garden appeared in religious architecture in Aleppo during the Ottoman period especially in the buildings that were constructed according to the foreign Ottoman style such as the back garden of al-Bahramiyyah mosque in al-Jallum district 991 A.H/ 1583 A.D (Abd alRazik. 2017) (fig. 5). The effect of this garden extended to some examples of the buildings that followed the local plan to gather also between the features of the local and foreign style. 
Among the examples of these buildings, the mosque of Aghajiq 993 A.H/ 1585 A.D, which includes a plan that collects between the local and the Ottoman plan as its sanctuary follows the local plan, at the same time, the sanctuary is fronted by an aisle overlooks to the courtyard with a triple arcade (Othman, 1992). Also, the mosque includes a garden that surrounded the sanctuary from the south, west, and east sides. Both the aisle that fronted the sanctuary and the garden is concerned with the Ottoman style and appeared in Aleppo in contemporary the Ottoman period (fig. 15).

In addition to the mosque of Aghajiq, there are many examples of the buildings that collect between the local and the Ottoman plan. These buildings are similar in their sanctuaries which were constructed according to the local plan and include the aisle that fronted the sanctuary, this aisle distinguishes the Ottoman plan such as the mosque of Qadi Askar 1097 A.H/ 1685 A.D which includes an aisle with duple arcade fronted its sanctuary. This applied also to the mosque of Hajj Musa 1176 A.H/ 1762 A.D (fig. 16); it includes a sanctuary with a local plan fronted by an aisle that overlooks the courtyard by a five-arches arcade (Othman, 2009). Among these also, the mosque of Souk al-Zarab 1286 A.H/ 1861 A.D that is fronted by a duple arcade, and the mosque of Salih al-Hal 1317 A.H/ 1899 A.D which is fronted by an aisle with a four-arches arcade.
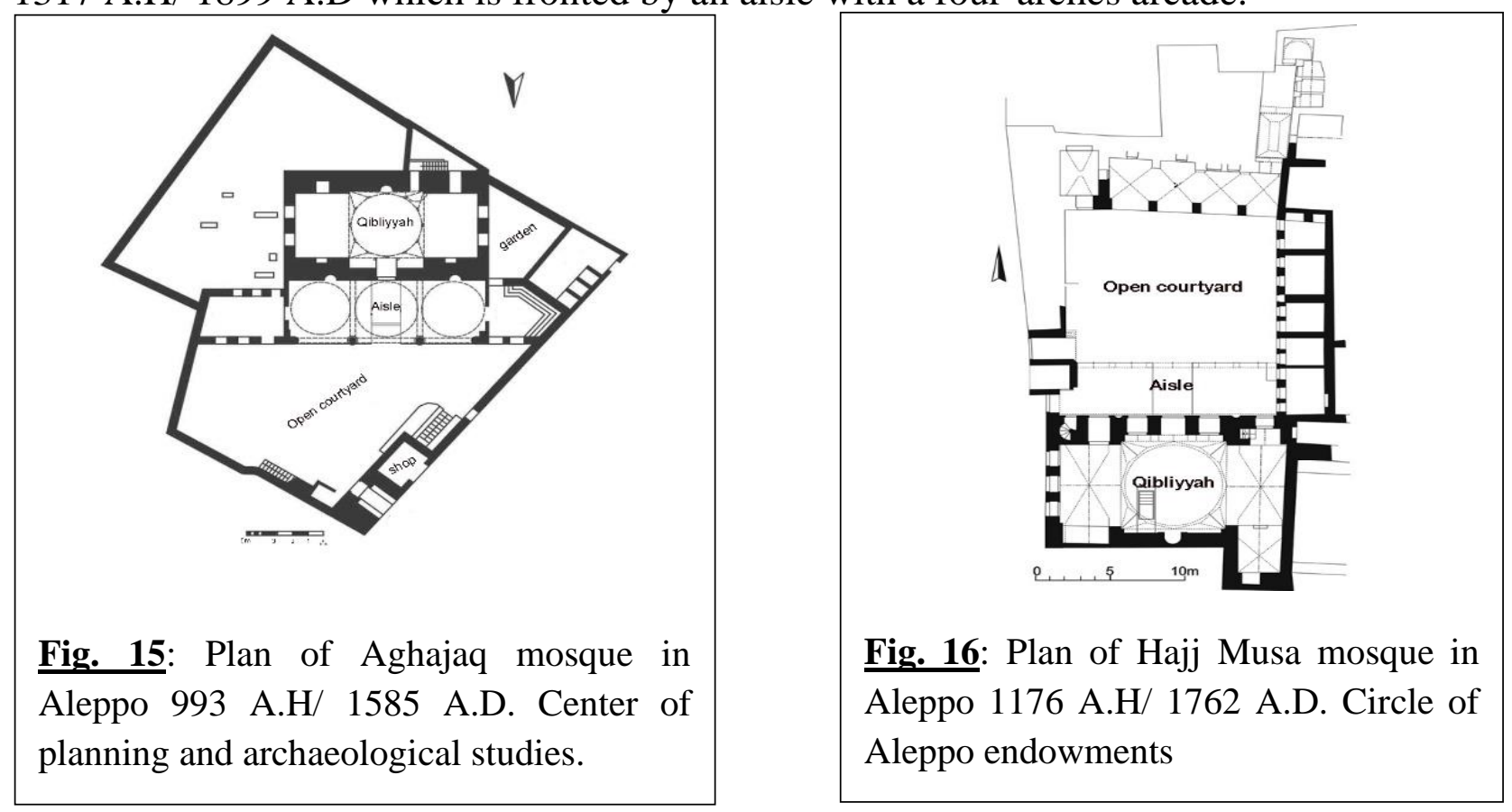

From the preceding, it is clear that the plans of the religious architecture that were constructed in Aleppo during the Ottoman period were subjected to many influences, some of these influences came to the city with the Turkish Ottoman after they controlled the city. Whereas the others are the inherited local styles that rooted in the city since the earlier periods. The following table (Table 1) shows the style of the religious building' plans that constructed according to the various influences during the Ottoman period. 
Table 1: shows the style of the plans of the religious buildings in Aleppo during the Ottoman period and the different influences on those plans.

\begin{tabular}{|c|c|c|c|}
\hline $\begin{array}{l}\text { Plan } \\
\text { style/ } \\
\text { No. }\end{array}$ & $\begin{array}{c}\text { Buildings constructed } \\
\text { according to the foreign } \\
\text { Ottoman plan } \\
\end{array}$ & $\begin{array}{c}\text { Buildings constructed } \\
\text { according to the local } \\
\text { inherited plan }\end{array}$ & $\begin{array}{c}\text { Buildings gather between } \\
\text { the Ottoman and local } \\
\text { plan }\end{array}$ \\
\hline 1 & $\begin{array}{l}\text { The mosque of Abi al- } \\
\text { Darajin in al-Jallum district } \\
\text { 950 A.H/ } 1544 \text { A.D. }\end{array}$ & $\begin{array}{l}\text { The mosque of al-Kizwani in } \\
\text { al- aqabah district } 928 \text { A.H/ } \\
\text { 1521 A.D. }\end{array}$ & $\begin{array}{l}\text { Aghajaq mosque in } \\
\text { Sajlikhan Tahtani district } \\
\text { 973 A.H/ } 1566 \text { A.D. }\end{array}$ \\
\hline 2 & $\begin{array}{l}\text { The mosque and madrasa of } \\
\text { al-Khustrawiyyah beside the } \\
\text { citadel } 951 \text { A.H/ } 1544 \text { A.D. }\end{array}$ & $\begin{array}{l}\text { Al-Mu'llaq mosque in souk al- } \\
\text { sabun } 931 \text { A.H/ } 1524 \text { A.D. }\end{array}$ & $\begin{array}{l}\text { Abu Bakr tekiyyia } 10^{\text {th }} \\
\text { A.H/ } 16^{\text {th }} \text { A.D century. }\end{array}$ \\
\hline 3 & $\begin{array}{l}\text { The mosque of al-'adiliyyah } \\
\text { south west of the citadel } 963 \\
\text { A.H/ } 1555 \text { A.D. }\end{array}$ & $\begin{array}{l}\text { The mosque of al-Khawaja in } \\
\text { al-Baiyadah district } 946 \text { A.H/ } \\
\text { 1539 A.D. }\end{array}$ & $\begin{array}{l}\text { Al-Ikhlasiyyah tekiyyah in } \\
\text { al-Bayadah district } 1044 \\
\text { A.H/ } 1634 \text { A.D. }\end{array}$ \\
\hline 4 & $\begin{array}{l}\text { The mosque of al-Hamawi } \\
\text { beside the citadel } 968 \text { A.H/ } \\
1561 \text { A.D. }\end{array}$ & $\begin{array}{l}\text { Al-Maghazli mosque in al- } \\
\text { Maghazli district } 1046 \text { A.H/ } \\
\text { 1636 A.D. }\end{array}$ & $\begin{array}{l}\text { Qadi Askar mosque in } \\
\text { Qadi Askar district } 1097 \\
\text { A.H/ } 1685 \text { A.D. }\end{array}$ \\
\hline 5 & $\begin{array}{l}\text { The mosque of Khan al- } \\
\text { Jumruk inside the Khan } 982 \\
\text { A.H/ } 1575 \text { A.D. }\end{array}$ & $\begin{array}{l}\text { Al-Baq mosque in Bazzah } \\
\text { square } 1047 \text { A.H/ } 1637 \text { A.D. }\end{array}$ & $\begin{array}{l}\text { Al-Hajj Musa mosque in } \\
\text { al-Siwiqa } 1177 \text { A.H/ } 1763 \\
\text { A.D. }\end{array}$ \\
\hline 6 & $\begin{array}{l}\text { The mosque al- } \\
\text { Bahramiyyah in al-Jallum } \\
\text { district 991 A.H/ } 1583 \text { A.D. }\end{array}$ & $\begin{array}{l}\text { Al-Balaț mosque in al-Balaṭ al- } \\
\text { Fawqani district } 1061 \text { A.H/ } \\
\text { 1650 A.D. }\end{array}$ & $\begin{array}{l}\text { Al-'ashuriyyah mosque in } \\
\text { Qal'it al-Shirif } 1244 \text { A.H/ } \\
\text { 1828 A.D. }\end{array}$ \\
\hline 7 & $\begin{array}{l}\text { Al-Othmaniyyah madrasa } \\
\text { (al-Rida'iyyah) in al- } \\
\text { Farafrah district } 1141 \text { A.H/ } \\
\text { 1730 A.D. }\end{array}$ & $\begin{array}{l}\text { Ibshir pasha mosque in al- } \\
\text { Jadidah district } 1063 \text { A.H/ } \\
1652 \text { A.D. }\end{array}$ & $\begin{array}{l}\text { Souq al-Zarab mosque in } \\
\text { Souq al-Zarab district } 1286 \\
\text { A.H/ } 1889 \text { A.D. }\end{array}$ \\
\hline 8 & $\begin{array}{l}\text { Al-Ahmadiyyah madrasa in } \\
\text { al-Jallum district } 1165 \text { A.H/ } \\
\text { 1751 A.D. }\end{array}$ & $\begin{array}{l}\text { Al-Sha'baniyyah madrasa in } \\
\text { al-Farafrah district } 1085 \text { A.H/ } \\
1674 \text { A.D. }\end{array}$ & $\begin{array}{l}\text { Al-Aḥmadi mosque in Jub } \\
\text { al-Aḥmadi } 1293 \text { A.H/ } 1876 \\
\text { A.D. }\end{array}$ \\
\hline 9 & $\begin{array}{l}\text { The mosque of al- } \\
\text { Kamaliyyah in al-'aqabah } \\
\text { district } 1187 \text { A.H/ } 1773 \\
\text { A.D. }\end{array}$ & $\begin{array}{l}\text { Barsin mosque in Briyah al- } \\
\text { Maslakh } 1095 \text { A.H/ } 1683 \text { A.D. }\end{array}$ & $\begin{array}{l}\text { Hassan Mosque in al- } \\
\text { Kallasah district } 1299 \text { A.H/ } \\
\text { 1881 A.D }\end{array}$ \\
\hline 10 & $\begin{array}{l}\text { The mosque of Zaki pasha } \\
\text { in al-isama iliyyah district } \\
1316 \text { A.H/ } 1898 \text { A.D. }\end{array}$ & $\begin{array}{l}\text { Al-Mashațiyyah mosque in al- } \\
\text { Mashațyyah district } 1134 \text { A.H/ } \\
1724 \text { A.D. }\end{array}$ & $\begin{array}{l}\text { Salih al-Hal mosque in Bab } \\
\text { al-Hadid } 1317 \text { A.H/ } 1899 \\
\text { A.D. }\end{array}$ \\
\hline 11 & $\begin{array}{l}\text { Al-Khashabiyyah Turbah in } \\
\text { zuqaq abi al-Darajin } 1317 \\
\text { A.H/ } 1899 \text { A.D. }\end{array}$ & $\begin{array}{l}\text { Al-Arba in mosque in al- } \\
\text { 'aqabah district } 1147 \text { A.H/ } \\
1734 \text { A.D. }\end{array}$ & 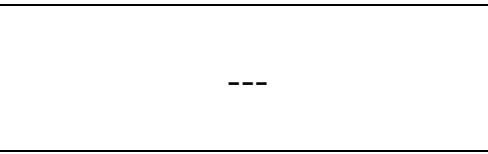 \\
\hline 12 & $\begin{array}{l}\text { Al-Hilaliyah zawiyah in al- } \\
\text { Jallum district } 1205 \text { A.H/ } \\
1790 \text { A.D. }\end{array}$ & $\begin{array}{l}\text { Al-Kawakibiyyah madrasa in } \\
\text { al-Jallum district } 1167 \text { A.H/ } \\
\text { 1753 A.D. }\end{array}$ & --- \\
\hline 13 & 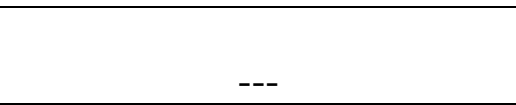 & $\begin{array}{l}\text { Al-Nabi Kalib mosque in al- } \\
\text { Fariq garden } 1195 \text { A.H/ } 1780\end{array}$ & --- \\
\hline
\end{tabular}


The local and foreign influences on religious architecture in Aleppo during the Ottoman period

\begin{tabular}{|c|c|c|c|}
\hline & & A.D. & \\
\hline 14 & --- & $\begin{array}{l}\text { Al- uqailiyyah zawiya in al- } \\
\text { Jadidah district } 1211 \text { A.H/ } \\
\text { 1796 A.D. }\end{array}$ & --- \\
\hline 15 & --- & $\begin{array}{l}\text { Shakir Agha mosque in Shakir } \\
\text { agha district } 1217 \text { A.H/ } 1802 \\
\text { A.D. }\end{array}$ & --- \\
\hline 16 & --- & $\begin{array}{l}\text { Al-Sayyasiyyah madrasa in al- } \\
\text { Bayadah district } 1249 \text { A.H/ } \\
\text { 1833 A.D. }\end{array}$ & --- \\
\hline 17 & --- & $\begin{array}{l}\text { Al-Isma iliyyah madrasa in al- } \\
\text { Farafrah district } 1255 \text { A.H/ } \\
\text { 1839 A.D. }\end{array}$ & --- \\
\hline 18 & --- & $\begin{array}{l}\text { Al-Umari mosque in al- } \\
\text { Saffahiyyah district } 1276 \text { A.H/ } \\
\text { 1859 A.D. }\end{array}$ & --- \\
\hline 19 & --- & $\begin{array}{l}\text { Maqar al-Anbiyaa mosque in } \\
\text { Dakakin Hijij district } 1278 \\
\text { A.H/ } 1861 \text { A.D. }\end{array}$ & --- \\
\hline 20 & --- & $\begin{array}{l}\text { The mosque of Ali al-Rumi } \\
\text { inside Bab Antakya } 1284 \text { A.H/ } \\
1867 \text { A.D. }\end{array}$ & --- \\
\hline 21 & --- & $\begin{array}{l}\text { Al-Dali mosque in Tali ran } \\
\text { district } 1300 \text { A.H/ } 1882 \text { A.D. }\end{array}$ & --- \\
\hline 22 & --- & $\begin{array}{l}\text { Zain al-Din al- ijji zawiyah } \\
1303 \text { A.H/ } 1885 \text { A.D. }\end{array}$ & --- \\
\hline 23 & --- & $\begin{array}{l}\text { Al-Mar ashli mosque in al- } \\
\text { Nahasin souk } 1303 \text { A.H/ } 1885 \\
\text { A.D. }\end{array}$ & --- \\
\hline 24 & --- & $\begin{array}{l}\text { Al-'ubati mosque in al- 'aqabah } \\
\text { district } 1304 \text { A.H/ } 1886 \text { A.D. }\end{array}$ & --- \\
\hline 25 & --- & $\begin{array}{l}\text { Al-Hashimiyyah madrasa in al- } \\
\text { Farafra district } 1308 \text { A.H/ } 1890 \\
\text { A.D. }\end{array}$ & --- \\
\hline 26 & --- & $\begin{array}{l}\text { Al-Sinkri mosque in al- } \\
\text { Bayadah district } 1311 \text { A.H/ } \\
\text { 1893 A.D. }\end{array}$ & --- \\
\hline 27 & --- & $\begin{array}{l}\text { Al-Abraj mosque in } \text { Jub } \\
\text { Qaraman district } 1313 \text { A.H/ } \\
\text { 1895 A.D. }\end{array}$ & --- \\
\hline 28 & --- & $\begin{array}{l}\text { Al-Nuhiyyah mosque in Aqyul } \\
\text { district } 1313 \text { A.H/ } 1895 \text { A.D. }\end{array}$ & --- \\
\hline 29 & --- & $\begin{array}{l}\text { Al-Tinah mosque in Aqyul } \\
\text { district } 1313 \text { A.H/ } 1895 \text { A.D. }\end{array}$ & --- \\
\hline
\end{tabular}


JOURNAL OF THE FACULTY OF ARCHAEOLOGY -VOLUME 25 -2022

\begin{tabular}{|l|l|l|l|}
\hline 30 & - & $\begin{array}{l}\text { Al-Safa mosque in Jub al-Safa } \\
\text { district 1316 A.H/ 1898 A.D. }\end{array}$ & --- \\
\hline 31 & --- & $\begin{array}{l}\text { Alam al-Din Balabani mosque } \\
\text { in al-Jubilah district 1318 A.H/ } \\
\text { 1900 A.D. }\end{array}$ \\
\hline 32 & $-\begin{array}{l}\text { Al-A jam mosque in al-A jam } \\
\text { district 1318 A.H/ 1900 A.D. }\end{array}$ & - \\
\hline 33 & --- & $\begin{array}{l}\text { Al-Dilyuwati mosque in al- } \\
\text { Frafrah district 1323 A.H/ } \\
\text { 1905 A.D. }\end{array}$ \\
\hline 34 & $-\begin{array}{l}\text { Turkmanjak mosque in al- } \\
\text { Mawirdi district 1330 A.H/ } \\
\text { 1912 A.D. }\end{array}$ \\
\hline
\end{tabular}

\section{The architectural elements:}

The architectural elements that were used in the religious architecture in Aleppo during the Ottoman period are varied. Both the local and foreign styles appeared in this period and the local elements has a great effect side by side with the Ottoman elements. Although this period included several buildings that were completely constructed according to the Ottoman plan, they were not devoid of the local influences in their architectural details. Moreover, many buildings that were constructed according to the local plans included many influences of the foreign Ottoman styles. Furthermore, there are many architectural elements that were performed according to the Ottoman style but they were locally treated to appear in a new feature that gather between the foreign and the local style.

\subsection{The Facades:}

Generally, the external facades of the Ottoman architecture characterize by hugeness and the richness in their decorations (al-Banna, 2018) this feature which the Ottomans inherited from the Seljuk architecture (Badr, 2002). Whereas, the external facades of the religious buildings in Aleppo during the Ottoman period characterized by simplicity as they were a continuation to the local styles (Othman, 1992).

Accordingly, all façades were built from stone and completely devoid of decorations except for the entrance area that was decorated with carved decorations or piebald decorations in most cases. This feature was followed during the Ayyubid and Mamluk periods and continued during the Ottoman era. So that, we can hardly differentiate between the facades of the earlier periods and those that date back to the Ottoman era, which asserts the local influences in this regard.

Among the examples that support the preceding, the external facades of alKhusrawiyyah madrasa 951 A.H/ 1544 A.D, which constructed according to the foreign Ottoman style and characterizes on the city's buildings by four free facades overlook to the citadel square that were supposed to be decorated. However, its external facades were not taken into the architect's care, so they were simple and devoid of decorations (pl. 1). 
This applied also to all monuments that were constructed according to the Ottoman style such as the mosque of al-'adihiyyah 963 A.H/ 1555 A.D, the mosque of al-Bahramiyyah 991 A.H/ 1583 A.D, and al-Othmaniyyah madrasa 1141 A.H/ 1731 A.D (pl. 2).

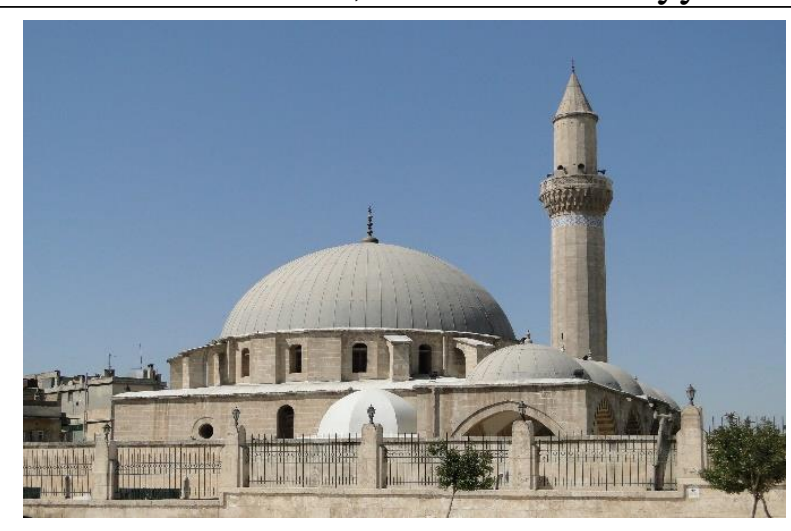

Pl. 1: Shows the simplicity of the facades of al-Khusrawiyyah madrasa in Aleppo 951 A.H/ 1544 A.D according to the local styles. By the author.

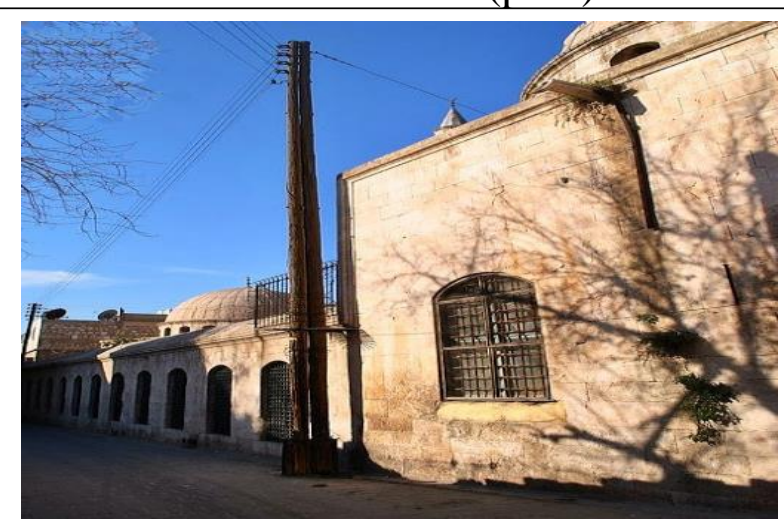

Pl. 2: Shows the simplicity of the facades of al-Othmaniyyah madrasa in Aleppo 1141 A.H/ 1730 A.D according to the local styles. By the author.

It can be said the Ottoman influence occurred in the internal facades of the sanctuary in the buildings that were constructed according to the Ottoman style, where the architect took care of these facades as if they were the external facades. Among the decorative features of these facades, the arches of the aisle that fronted the sanctuary which decorated with stone and marble decorations with black and yellow colors according to the piebald style al-moshahhar. Moreover, the areas around the entrance of the sanctuary and the areas around the windows are decorated with the same decorations and surmounted with panels of pottery tiles. Furthermore, the entrance of the sanctuary that mediated the façade decorated according to the Ottoman style, where it surmounted by a curved arch composes of colored engaged voussoirs and topped by stone stalactites arranged in a triangle shape according to the Ottoman entrances, which inspired from Seljuk architecture. Also, on both the right and left sides of the entrance, there is a mihrab surmounted by stalactites arranged in the same shape. Accordingly, the internal façades of the sanctuary, not the external façades, reflect the Ottoman style, which applied to many examples such as the façade of the sanctuary of al-Khusrawiyyah madrasa 951 A.H/ 1544 A.D (pl. 3), and the façade of the sanctuary of al- 'Adiliyyah mosque 963 A.H/ 1555 A.D (pl. 4). 


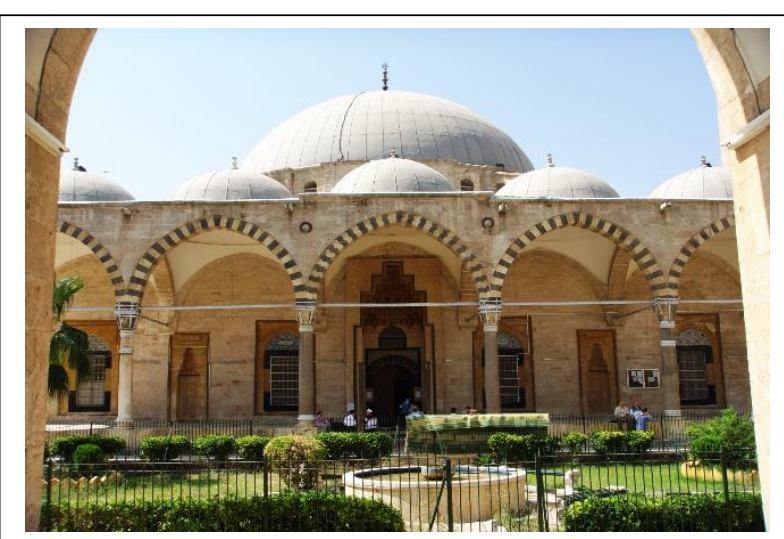

Pl. 3: The façade of the sanctuary alQibliyyah of al-Khusrawiyyah madrasa 951 A.H/ 1544 A.D according to the Ottoman styles. By the author.

As for the buildings of the local plan, their external facades were far from the Ottoman style and a true extension to the local styles, not only in their general shape but also in distribution of their architectural elements. It is customary since the earlier periods that the façade is simple and mediated by the entrance. In most cases, the minaret rises above the entrance or above one of its two corners. This applied to many examples of the buildings of this period such as Ibshir pasha mosque in al-Jadidah district 1063 A.H/ 1652 A.D (pl. 5), al-Sha baniyyah madrasa in al-Farafrah district 1085 A.H/ 1674 A.D, al-Mashatiyyah mosque in al-Mashatiyyah district 1134 A.H/ 1721 A.D, al-Arba in mosque in al-'aqabah district 1147 A.H/ 1734 A.D, and al-Isma iliyyah madrasa in al-Frafrah district 1255 A.H/ 1839 A.D.

\subsection{The entrances:}

Some examples of the religious architecture that were constructed according to the Ottoman style included a new style of the entrances, which did not appear in Aleppo before this period. This style of entrance composes of a deep recess surmounted by a semi-dome occupied by rows of stalactites arranged in conical shape ${ }^{(11)}$. It appeared on a limited scale especially in the entrances of the sanctuary such as the entrance of the sanctuary of al-Khusrawiyyah madrasa 951 A.H/ 1544 A.D (pl. 6, a), and the entrance of the sanctuary of al-' adiliyyah mosque 963 A.H/ 1555 A.D (pl. 6, b).

Besides this style, the local influences formalized also the shape of the entrances during this period, where the majority of their examples were a continuation to the styles 
of the local entrances. This is applied to the buildings that were constructed according to the Ottoman style and the buildings of the local style. Among the examples that assert the local influences on the entrances of the Ottoman style buildings, the entrance of the sanctuary of al-Bahramiyyah mosque in al-Jadidah district 991 A.H/ 1583 A.D (pl. 7, a) which was a repeat copy with minor changes of the entrance of the mosque of Othman Ibn Ogilbik in al-Bayadah district which constructed during the Mamluk period in 881 A.H/ 1477 A.D (pl. 7, b) (Abd al-Razik, 2019). Both two entrances compose of a deep recess surmounted by a pointed arch that includes carved floral decorations depends on stalactites (Abd al-Razik, 2017). The two entrances are identical in their shape and their decorations to the extent that those who look at them think that their architect was the same one, which asserts the local influence although the mosque was constructed according to the Ottoman style. Likewise, the main entrance of the same mosque and the entrance of al-Othmaniyyah madrasa are also a continuation to the local style, where they compose of a recess surmounted by a pointed arch except for the curved arch that surmounted the entry open instead of the straight arch in local style.

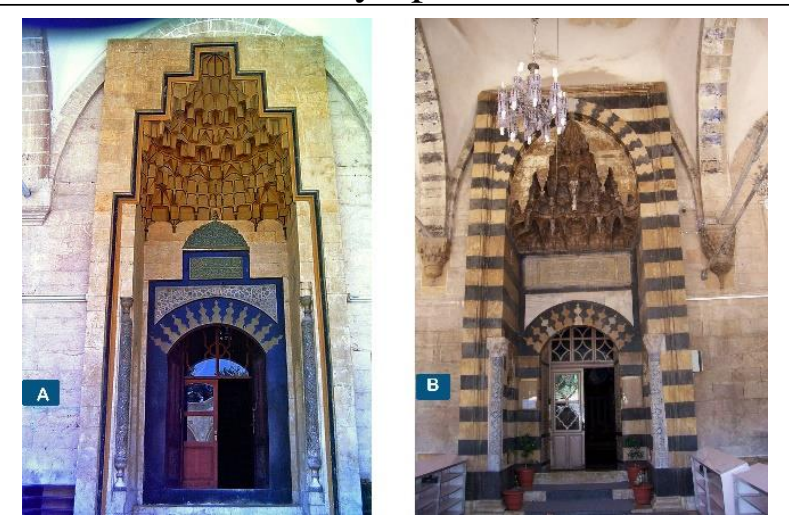

Pl. 6: Entrances on Ottoman style: (a) the entrance of the sanctuary of al-Khsrawiyyah madrasa $(\mathbf{b})$ the entrance of the sanctuary of al-' adiliyyah mosque. By the author.
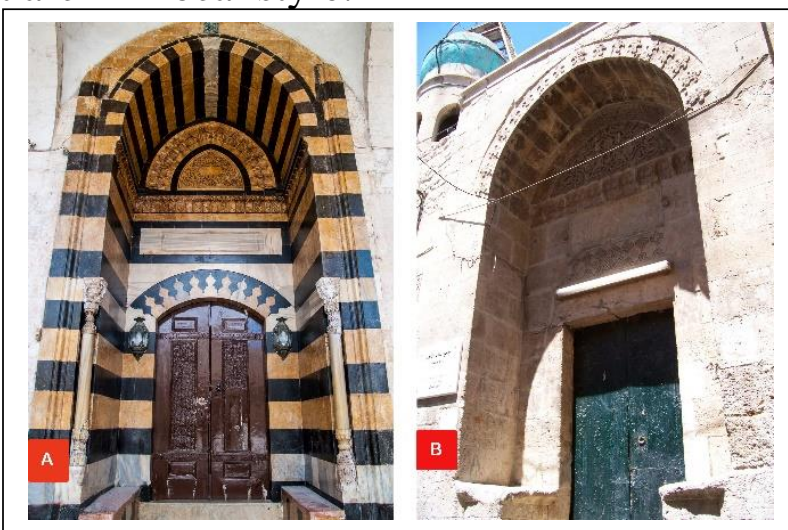

Pl. 7: (a) the entrance of the sanctuary of alBahramiyyah mosque 991 A.H/ 1583 A.D $\underline{\text { (b) }}$ the entrance of Ogelbek mosque 881 A.H/ 1477 A.D, Aleppo. By the author.

The entrance surmounted by a semi-dome occupied by stalactites ${ }^{(12)}$ is considered one of the most famous ones that appeared in Aleppo since the earlier periods and its influence continued during the Ottoman period. Firstly, it appeared since the Ayyubid periods such as the entrance of al-Shazbakhtiyyah madrasa 589 A.H/ 1193 A.D and alFirdus madrasa 633 A.H/ 1236 A.D (pl. 8, a). Then, It continued during the Mamluk period such as the entrance of Minkali Bugha mosque 768 A.H/ 1366 A.D (Abd al-Razik, 2016), al-Twashi mosque 774 A.H/ 1372 A.D, and al-Atrush mosque 801 A.H/ 1399 A.D. Finally, its influence continued during the Ottoman period such as the entrance of al-Kamaliyyah mosque in al-' aqabah district 1187 A.H/ 1773 A.D (pl. 8, b).

Among the local styles of the entrances whose influence continued during the Ottoman period, those entrance that was surmounted by the triple-arch al-'aqd almada ${ }^{\prime} i^{(13)}$. It appeared in Aleppo since the Zanki period in al-Maqdamiyyah madrasa 
564 A.H/ 1168 A.D (pl. 9, a), and appeared in al-Kakhtalli mosque beside Bab Qinnasrin (Othman, 1992). The influence of this entrance continued to the Ottoman period, where it appeared in the entrance of the sanctuary of Abu Bakr al-wafa'i Teykia $10^{\text {th }}$ A.H/ $16^{\text {th }}$ A.D century (pl. 9, b), the entrance of Zaki Pasha mosque in al-Isma iliyyah district 1316 A.H/ 1898 A.D, and the north entrance of the great Umayyad mosque which rebuilt during the Ottoman period.

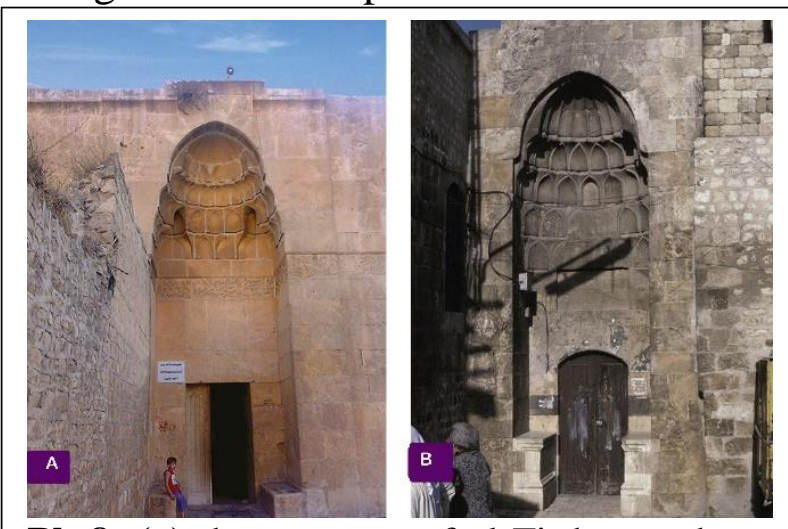

Pl. 8: $\underline{\text { (a) }}$ the entrance of al-Firdus madrasa 633 A.H/ 1236 A.D $\underline{(\text { b) }}$ the entrance of alKamaliyyah mosque 1187 A.H/ 1773 A.D, Aleppo. By the author.
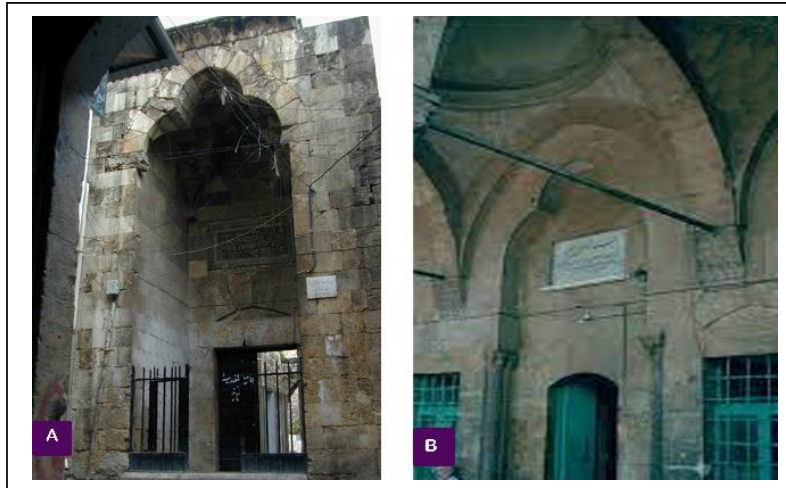

Pl. 9: (a) the entrance of Maqdamiyyah madrasa 564 A.H/ 1168 A.D $\underline{(\text { b) })}$ the entrance of the sanctuary of Abu Bakr alWafa'i Teykia $10^{\text {th }} / 16$ th century, Aleppo. By the author.

In addition to the preceding, the entrances of the Ottoman period did not have a continuation to the local style for their shapes only, but also for their relationship with the minaret, where the entrances in most cases used as a base of the minaret. Among these, the mosque of Aghajaq 973 A.H/ 1566 A.D, the entrance of al-Balat al-Fawqani mosque 1061 A.H/ 1650 A.D, and the entrance of al-Mashatiyyah mosque 1134 A.H/ 1721 A.D.

\subsection{The minarets:}

There were many styles of the minaret that appeared in Aleppo during the Ottoman period and were submitted to many influences (table 2). During this period, a new style appeared that was not known before this period ${ }^{(14)}$, this style composes of a ribbed shaft ended by a projecting balcony depended on stone stalactites; a smaller shaft surmounts this balcony with the same shape ended with a conical cap covered with lead tiles. This composition reflects the shape of the ottoman minaret in Istanbul and other provinces of the Ottoman state (Freely, 2011). Among the examples of this minaret in the buildings of the Ottoman plan, the minaret of al-Khusrawiyyah madrasa 951 A.H/ 1544 A.D (pl. 10, a), which considered the first example that was constructed on this style, the minaret of al- adiliyyah mosque 963 A.H/ 1555 A.D (pl. 10, b), the minaret of al Bahramiyyah mosque 991 A.H/ 1583 A.D (pl. 10, c), the minaret of al-Othmaniyyah madrasa 1141 A.H/ 1730 A.D, and the minaret of Zaki pasha mosque 1316 A.H/ 1898 A.D (pl. 10, d). It also appeared in the Buildings of the local plan in one example only in the mosque of al-Kizwani 1237 A.H/ 1821 A.D (pl. 10, e), which characterizes by the cylindrical shape instead of the octagonal shape. 


\section{The local and foreign influences on religious architecture in Aleppo during the}

Ottoman period

The majority of these minarets kept the Ottoman shape and abandoned the elements which commonly used in the local minarets such as the sunshade al-mazzlah that crowned the balcony to protect al-Mu'azin from the rain and the sun -rays although the climate of the city did not change which assert the foreign Ottoman effect in this regard. However, some examples of the Ottoman minaret were built with Aleppo local influences to gathered between the Ottoman and the local shape at the same time, which asserts the local influences on the foreign Ottoman minarets. Among these examples, the minaret of al-Hamawi mosque 968 A.H/ 1566 A.D, which was built according to the Ottoman style, where it composes of a ribbed shaft and a conical cap, at the same time, the architect added a sunshade above its balcony, which considered among the features of the local minaret (pl. 11, a). This applied also to the minaret of Abu Bakr al-Wafa'i Tekyia $10^{\text {th }}$ A.H/ $16^{\text {th }}$ A.D century, and the minaret of al-Kamaliyyah mosque 1187 A.H/ 1773 A.D (pl. 11, b), as the conical cap replaced by a small dome in both minarets. Among these also, the minaret of al-Abaraj mosque 1313 A.H/ 1895 A.D (pl. 11, c), which resemble the aforementioned minaret of al-Hamawi mosque.

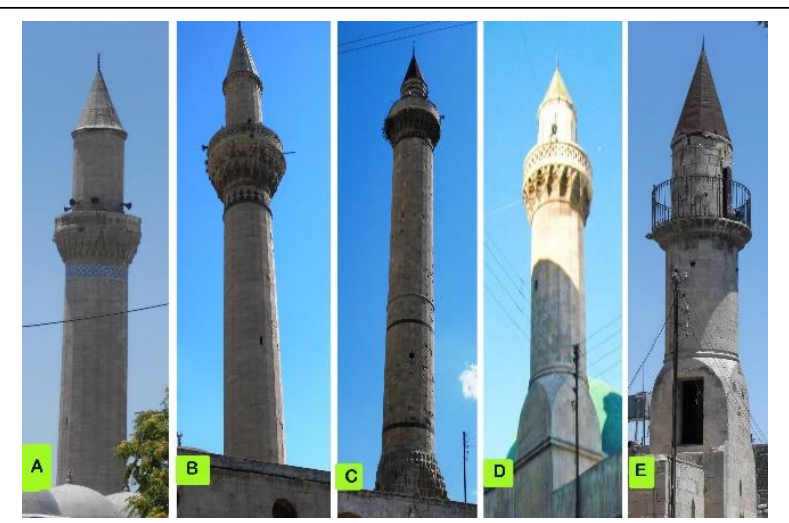

Pl. 10: Minarets on Ottoman style: (a) alKhusrawiyyah 951 A.H/ 1544 A.D $\underline{(\mathbf{b})}$ al'Adiliyyah 963 A.H/ 1555 A.D $\underline{(\mathbf{c})}$ alBahramiyyah 991 A.H/ 1583 A.D (d) Zaki pasha 1316 A.H/ 1898 A.D (e) al-Kizwani 1237 A.H/ 1821 A.D, Aleppo. By the author.
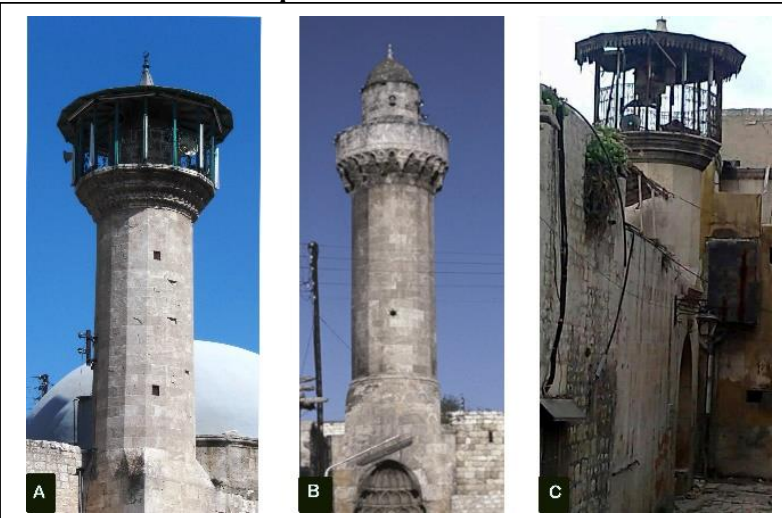

Pl. 11: Minarets gathered between the Ottoman and local style: (a) al-Hamawi 968 A.H/ 1566 A.D (b) al-Kamaliyyah 1187 A.H/ 1773 A.D $\underline{(\mathbf{c})}$ al-Abraj 1313 A.H/ 1895A.D, Aleppo. By the author.

Besides the Ottoman minarets and the minarets that gather between the Ottoman and the local minarets, there are many examples built according to the pure local styles of the Mamluk minarets in Aleppo, which compose of an octagonal shaft ends by a projecting balcony surmounted by a sunshade. This shape is considered a direct influence of the Egyptian minaret with some local treatments. This style spread in religious architecture during the Ottoman period especially in the buildings that were constructed according to the local plan such as the minaret of Aghajaq mosque 973 A.H/ 1566 A.D (pl. 12, a), Barsin mosque 1095 A.H/ 1683 A.D, Qadi Askar mosque 1097 A.H/ 1685 A.D, al-Mashatiyyah mosque 1134 A.H/ 1721 A.D (pl. 12, b), al-Barraqiyyah Teykia 1239 A.H/ 1824 A.D, al-Tarinta iyah madrasa which rebuilt in 1293 A.H/ 1876 A.H (pl. 
12, c), and the minaret of al-Mawlawiyyah Teykia 1176 A.H/ 1762 A.D, which considered the most examples that influenced by the Egyptian minaret as it includes a pavilion above its octagonal shaft (pl. 12, d).

Another style of the minaret appeared in Aleppo during the Ottoman period that is considered a continuation to earlier styles. The minaret in this style depends on the cylindrical shaft, which previously appeared in the minaret of Mihmindar mosque $8^{\text {th }}$ A.H/ $14^{\text {th }}$ A.D century (Abd al-Razik, 2015) (pl. 13, a), and the minaret of Minkali Bugha mosque 769 A.H/ 1367 A.D (Abd al-Razik, 2016) (pl. 13, b). The origin of this minaret firstly began in the eastern Islamic world in Iran, central Asia, and Anatolia. Among its examples, the minaret of the mosque of Tariq-Khana in Damaghan 417 A.H/ 1026 A.D (Moline, 1979), (Bloom, 1989), Kalyan mosque in Bukhara 520 A.H/ 1127 A.D (pl. 13,c), and the minaret of Fabkint mosque in Bukhara 595 A.H/ 1198 A.D (al-Nimri, 1997). Then, this style became a characterized feature of the eastern minaret and moved to Aleppo during the Mamluk period. Finally, it continued during the Ottoman period as a local influence, where it appeared in the minaret of al-Maydani mosque 960 A.H/ 1553 A.D (pl. 13, d), which is identical to the minaret of mihmindar mosque. It applied also to the minaret of al-Balat al-Fawqani mosque 1061 A.H/ 1650 A.D, which is identical to the minaret of Minkali Bugha mosque, whereas it has a conical cap (pl. 13, e).

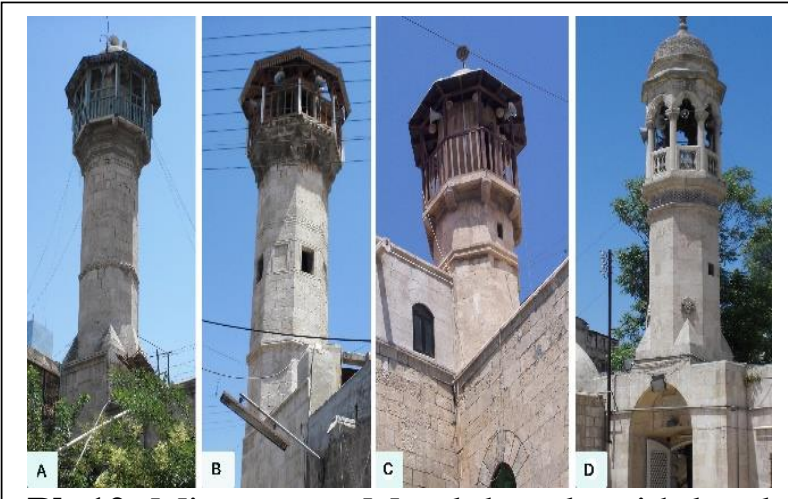

Pl. 12: Minarets on Mamluk style with local features: (a) Aghajaq 973 A.H/ $1566 \underline{(\text { b) }}$ alMashatiyyah 1134 A.H/ 1721 A.D $(\underline{\text { (c) })}$ alTarinta'iyyah 1293 A.H/ 1876 A.D $\underline{(\mathbf{d})}$ alMawlawiyyah 1315 A.H/ 1898 A.D, Aleppo. By the author.

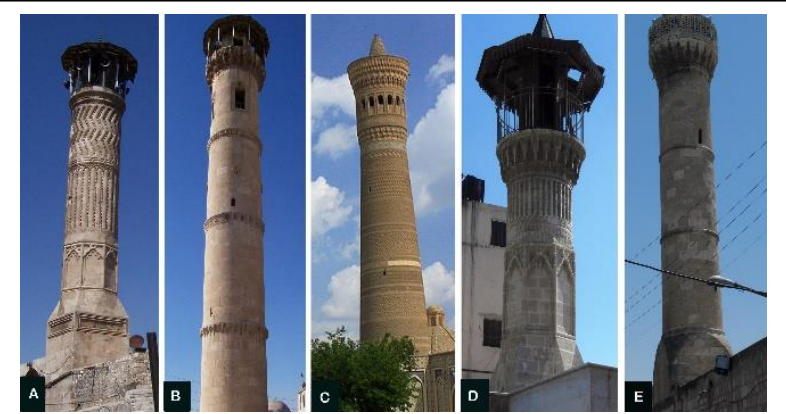

Pl. 13: Minarets with eastern influences: $\underline{\text { (a) }}$ Mehmendar mosque $8^{\text {th }} / 14^{\text {th }}$ century, Aleppo. (b) Minkali Bugha mosque 769 A.H/ 1367 A.D, Aleppo. (c) Kalyan mosque 520 A.H/ 1127 A.D, Bukhra. $\underline{(\mathbf{d})}$ alMaydani mosque 960 A.H/ 1553 A.D, Aleppo. (e) al-Balat al-Fawqani mosque 1061 A.H/ 1650 A.D, Aleppo.

The last style of the minarets that appeared in Aleppo during the Ottoman period was the symbolic minarets. It is considered a continuation of the local styles that appeared in the city before the Ottoman period (Abd al-Razik, 2019). This minaret is called by this name because it is very short to use for call to prayers, where it composes of a terrace with $60: 80 \mathrm{~cm}$ high and surmounted by a sunshade so that it does not add anything to the voice of the muezzin. This style of minaret did not limit to Aleppo or Syrian cities but spread in many examples of the provinces of Upper Egypt and Anatolia. 
In most cases, it is reached through a staircase inside the courtyard, so that it is known also as staircase minaret (Schacht, 1938).

This style of minarets widely spread in Aleppo before the Ottoman period such as the minaret of al-Shu ibiyyah mosque which was renewed in 545 A.H/ 1150 A.D (pl. 14, a), al'aqaba mosque 743 A.H/ 1342 A.D, Qasim al-Hariri mosque 765 A.H/ 1362 A.D, alQarnasiyyah madrasa 770 A.H/ 1368 A.D (pl. $14, b)$, and the minaret of the mosque of Othman Ibn Ogilbik 881 A.H/ 1477 A.D. It continued with the same shape to the minaret of the Ottoman period to assert the local influences in this regard. Among its examples, the minaret of al-Baq mosque 1047 A.H/ 1637 A.D, Ibshir pasha mosque 1063 A.H/ 1652 A.D (pl. 14, c), al-' ashuriyyah mosque 1244 A.H/ 1828 A.D, al-Isma iliyyah madrasa 1255 A.H/ 1839 A.D (pl. 14, d), alAhmadi mosque 1273 A.H/ 1876 A.D, and the minaret of al-A jam mosque 1318 A.H/

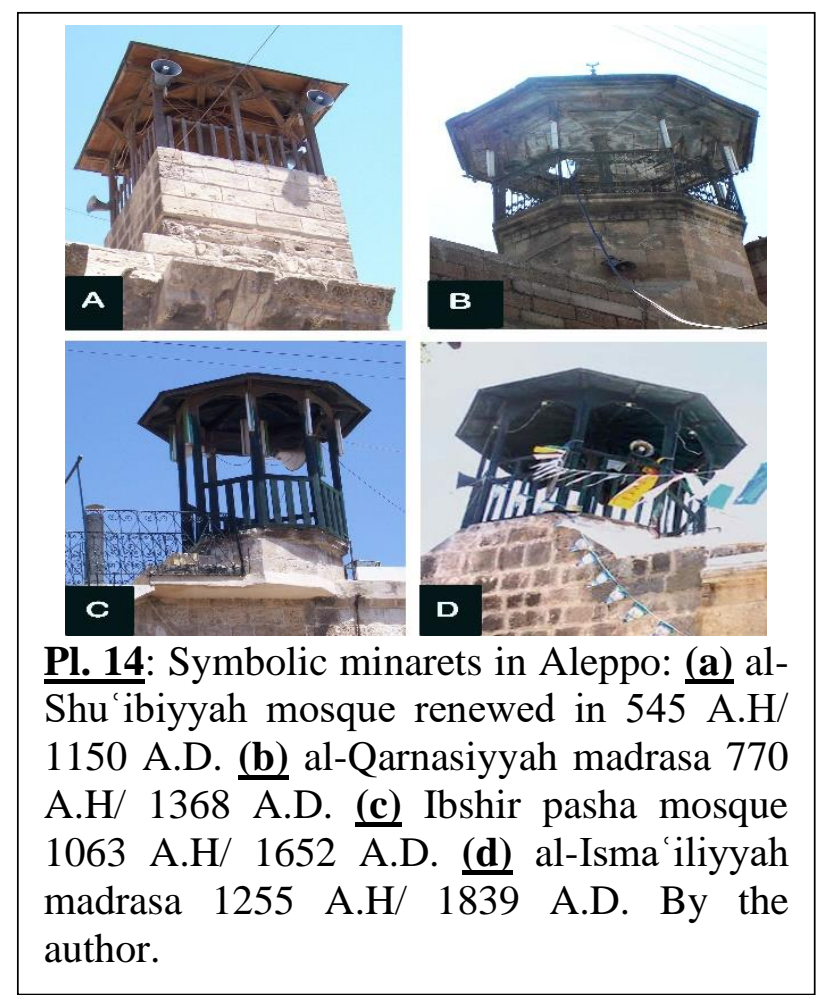
1900 A.D. In most cases, these minarets are associated with the small mosques, and perhaps this was in suitability with the simplicity of these mosques or to save the costs of the great minaret (Abd al-Razik, 2019).

Table 2: shows the style of Aleppo's minarets during the Ottoman period, according to the different influences on these minarets.

\begin{tabular}{|c|c|c|c|c|}
\hline $\begin{array}{l}\text { The Ottoman } \\
\text { minaret style }\end{array}$ & $\begin{array}{l}\text { The Ottoman } \\
\text { minaret style } \\
\text { influenced by } \\
\text { local elements }\end{array}$ & $\begin{array}{l}\text { The local minaret } \\
\text { style (Mamluk } \\
\text { minaret with } \\
\text { local feature) }\end{array}$ & $\begin{array}{c}\text { The foreign } \\
\text { eastern minaret } \\
\text { style }\end{array}$ & $\begin{array}{l}\text { The symbolic } \\
\text { minarets style }\end{array}$ \\
\hline $\begin{array}{l}\text { The minaret of al- } \\
\text { Kizwani mosque } \\
928 \text { A.H/ } 1521 \\
\text { A.D. }\end{array}$ & $\begin{array}{l}\text { The minaret of } \\
\text { al-Hamawi } \\
\text { mosque } 968 \\
\text { A.H/ 1566 A.D. }\end{array}$ & $\begin{array}{l}\text { The minaret of } \\
\text { Aghajaq mosque } \\
973 \text { A.H/ } 1566 \\
\text { A.D. }\end{array}$ & $\begin{array}{l}\text { The minaret of } \\
\text { al-Maydani } \\
\text { mosque } 960 \\
\text { A.H/ } 1553 \text { A.D. }\end{array}$ & $\begin{array}{l}\text { The minaret of } \\
\text { al-Baq mosque } \\
1047 \text { A.H/ } 1637 \\
\text { A.D. }\end{array}$ \\
\hline $\begin{array}{l}\text { The minaret of al- } \\
\text { Khisrawiyyah } \\
\text { madrasa 951 A.H/ } \\
\text { 1544 A.D. }\end{array}$ & $\begin{array}{l}\text { The minaret of } \\
\text { Abu Bakr al- } \\
\begin{array}{l}\text { Wafa } \\
1 \text { i Tykia } \\
10^{\text {th }} / 16^{\text {th }} \\
\text { century. }\end{array} \\
\end{array}$ & $\begin{array}{l}\text { The minaret of } \\
\text { Barsin mosque } \\
1095 \text { A.H/ } 1683 \\
\text { A.D. }\end{array}$ & 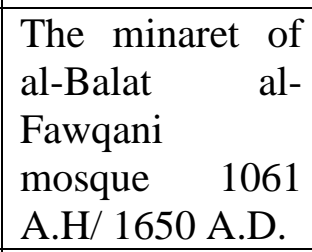 & $\begin{array}{l}\text { The minaret of } \\
\text { Ibshir pasha } \\
\text { mosque } 1063 \\
\text { A.H/ } \\
\text { 1652 A.D. }\end{array}$ \\
\hline $\begin{array}{l}\text { The minaret of al- } \\
\text { 'adiliyyah mosque } \\
963 \text { A.H/ } 1555 \\
\text { A.D. }\end{array}$ & $\begin{array}{l}\text { The minaret of } \\
\text { al-Kamaliyyah } \\
\text { Zawiyah } 1187 \\
\text { A.H/ } 1773 \text { A.D }\end{array}$ & $\begin{array}{l}\text { The minaret of } \\
\text { Qadi Askar } \\
\text { mosque } 1097 \text { A.H/ } \\
\text { 1685 A.D. }\end{array}$ & --- & $\begin{array}{l}\text { The minaret of } \\
\text { al- uqailiyyah } \\
\text { Zawiyah } 1211\end{array}$ \\
\hline
\end{tabular}


JOURNAL OF THE FACULTY OF ARCHAEOLOGY -VOLUME 25 -2022

\begin{tabular}{|c|c|c|c|c|}
\hline & & & & A.H/ 1796 A.D. \\
\hline $\begin{array}{l}\text { The minaret of al- } \\
\text { Bahramiyyah } \\
\text { mosque } 991 \quad \text { A.H/ } \\
1583 \text { A.D. }\end{array}$ & $\begin{array}{l}\text { The minaret of } \\
\text { al-Abraj mosque } \\
1313 \text { A.H/ } 1895 \\
\text { A.D. }\end{array}$ & $\begin{array}{l}\text { The minaret of al- } \\
\text { Mashatiyyah } \\
\text { mosque } 1134 \text { A.H/ } \\
\text { 1721 A.D. }\end{array}$ & --- & $\begin{array}{l}\text { The minaret of } \\
\text { Shakir Agha } \\
\text { mosque } 1217 \\
\text { A.H/ 1802 } \\
\text { A.D. }\end{array}$ \\
\hline $\begin{array}{l}\text { The minaret of al- } \\
\text { Othmaniyyah } \\
\text { madrasa } 1141 \text { A.H/ } \\
1730 \text { A.D. }\end{array}$ & --- & $\begin{array}{l}\text { The minaret of al- } \\
\text { Salehin mosque } \\
1144 \text { A.H/ } 1731 \\
\text { A.D. }\end{array}$ & --- & $\begin{array}{l}\text { The minaret of } \\
\text { al-'shuriyyah } \\
1244 \text { A.H/ } 1828 \\
\text { A.D. }\end{array}$ \\
\hline $\begin{array}{l}\text { The minaret of al- } \\
\text { Hajj Musa mosque } \\
1177 \quad \text { A.H/ } 1763 \\
\text { A.D. }\end{array}$ & --- & $\begin{array}{l}\text { The minaret of al- } \\
\text { Barraqiyyah Tekia } \\
1239 \text { A.H/ } 1824 \\
\text { A.D }\end{array}$ & --- & $\begin{array}{l}\text { The minaret of } \\
\text { al-Isma'iliyyah } \\
\text { madrasa } 1255 \\
\text { A.H/ } 1839 \text { A.D. }\end{array}$ \\
\hline $\begin{array}{l}\text { The minaret of } \\
\text { Zaki pasha mosque } \\
1316 \text { A.H/ } 1898 \\
\text { A.D. }\end{array}$ & --- & $\begin{array}{l}\text { The minaret of al- } \\
\text { Tarinta'iyah } \\
\text { madrasa } 1293 \\
\text { A.H/ } 1876 \text { A.D. }\end{array}$ & --- & $\begin{array}{l}\text { The minaret of } \\
\text { al-Ahmadi } \\
\text { mosque } 1293 \\
\text { A.H/ 1876 A.D. }\end{array}$ \\
\hline--- & -- & $\begin{array}{l}\text { The minaret of al- } \\
\text { Mawlawiyah } \\
\text { Tekia } 1176 \text { A.H/ } \\
1762 \text { A.D. }\end{array}$ & -- & $\begin{array}{l}\text { The minaret of } \\
\text { al-Mar'shli } \\
\text { mosque } 1303 \\
\text { A.H/ 1885 A.D. }\end{array}$ \\
\hline --- & --- & --- & --- & $\begin{array}{l}\text { The minaret of } \\
\text { Salih al-Hal } \\
\text { mosque } 1317 \\
\text { A.H/ 1899 A.D. }\end{array}$ \\
\hline--- & --- & --- & --- & $\begin{array}{l}\text { The minaret of } \\
\text { al-A jam } \\
\text { mosque } 1318 \\
\text { A.H/ } 1900 \text { A.D. }\end{array}$ \\
\hline
\end{tabular}

\subsection{The ceilings:}

A new style of the ceiling has appeared in the religious buildings of Aleppo since the beginning of the Ottoman period. This new style appeared particularly in the sanctuary al-Qibliyyah, which composes of a square area roofed by a huge dome that depends on the sidewalls without any columns. Moreover, the ceiling of the aisle that fronted the sanctuary which roofed by small or shallow domes. Generally, this style of ceiling characterizes Ottoman architecture and moved to the city of Aleppo with the Ottoman era (Atia, 2007).

This applied to the buildings that were constructed according to the Ottoman plan such as al-Khusrawiyyah madrasa 951 A.H/ 1544 A.D (fig. 3), al- 'adiliyyah mosque 963 A.H/ 1555 A.D (fig. 4), al-Bahramiyyah mosque 991 A.H/ 1583 A.D (fig. 5), alOthmaniyyah madrasa 1141 A.H/ 1730 A.D (fig, 6), al-Ahmadiyyah madrasa 1165 A.H/ 
1751 A.D, al-Kamaliyyah mosque 1187 A.H/ 1773 A.D, and Zaki Pasha mosque 1316 A.H/ 1898 A.D.

At the same time, the local styles affected the ceiling of the religious buildings of this period. The local style that was used in roofing the sanctuary in the earlier periods composed of a dome in the middle and a vault on its two sides. Among the examples of this style in the earlier periods, al-Sultaniyyah madras 620 A.H/ 1223 A.D (fig. 10), alFirdus madrasa 633 A.H/ 1236 A.D but the two vault replaced by two domes as alQibliyyah roofed with three domes, al-Tarita'iyyah madrasa 649 A.H/ 1251 A.D, Mihmindar mosque $8^{\text {th }}$ A.H/ $14^{\text {th }}$ A.D century (Abd al-Razik, 2015), Ashiqtumur mosque 773 A.H/ 1371 A.D (fig. 11), and Oghilbik mosque 881 A.H/ 1477 A.D (Abd al-Razik, 2019) (fig. 12). In case dividing the sanctuary into aisles through pillars and arcades, these aisles were dividing into square areas that were roofed with cross vaults. The first example of this style began in the great Umayyad mosque 92-99 A.H/ 710-717 A.D (Fares, 1997) (fig. 9), sometimes also, the mihrab square roofed by a dome and the other areas roofed by cross vaults such as al-Karimiyyah mosque which renewed in $654 \mathrm{~A} . \mathrm{H} /$ 1256 A.D (Abd al-Razik, 2020).

This local style continued for the ceiling in the religious buildings during the Ottoman period, which emphasized the local influences in this regard. Among these, the mosque of Aghajaq 973 A.H/ 1566 A.D (fig. 15), its sanctuary composes of a horizontal rectangular divided into three areas; the central one roofed by a dome while the other two sections roofed by pointed vaults, this style which considered a true effect for the local ceiling. This applied also to the mosque of Ibshir pasha 1063 A.H/ 1652 A.D (fig. 13), alSha'baniyyah madrasa 1085 A.H/ 1674 A.D, the mosque of Qadi Askar 1097 A.H/ 1685 A.D, the mosque of Hajj Musa 1176 A.H/ 1762 A.D (fig. 16), and the mosque of Salih alHal 1317 A.H/ 1899 A.D. Sometimes, the same style appeared with some changes such as the mosque of Souq al-Zarab 1286 A.H/ 1869 A.D that the central dome replaced by a cross vault.

The other local style of the ceiling, which depended on the cross vaults in all areas of the sanctuary with a dome in front of the mihrab square, continued also during the Ottoman period. The examples of this style appeared in the mosque of al-Baq 1047 A.H/ 1637 A.D, the mosque of al-Arba in 1147 A.H/ 1734 A.D, the mosque of al-Ahmadi 1293 A.H/ 1876 A.D, the mosque of Hassan 1299 A.H/ 1881 A.D, the mosque of alAbraj 1313 A.D/ 1895 A.D, and the mosque of al-A jam 1318 A.H/ 1900 A.D.

\subsection{The mihrabs:}

A new style of the mihrab appeared in the city of Aleppo during the Ottoman period. This new style of the mihrab characterizes by its stalactite cap, which reflected the foreign Ottoman influence as it did not previously appear in the local examples. Usually, the stalactites arranged inside the cap of the mihrab in a triangle shape, this shape which influenced by the Seljuk mihrabs such as the mihrab of the Ashraf Uğlu mosque in Beyşehir 699 A.H/ 1298 A.D (Atia, 2007) (pl. 15, a), the mihrab of Ilyas Bek mosque in Miltos 806 A.H/ 1404 A.D, and the mihrab of Sahib Ata mosque in Konya (Safwat, 2019). 
This new style of the mihrabs appeared in Aleppo in both the buildings that were constructed according to the Ottoman plan and the buildings that were constructed according to the local styles. Among its examples, the mihrab of Abi al-Darajin mosque 950 A.H/ 1544 A.D, the mihrabs of al- 'Adiliyyah mosque 963 A.H/ 1555 A.D (pl. 15, b), the mihrab of Aghajaq mosque 973 A.H/ 1566 A.D (pl. 15, c), the mihrab of Bahram Pasha mosque 991 A.H/ 1583 A.D, the mihrab of Ibshir pasha mosque 1063 A.H/ 1653 A.D (pl. 15, d), the mihrab of al-Hilaliyyah zawiya 1205 A.H/ 1790 A.D, and the mihrab of Salih al-Hal mosque 1317 A.H/ 1899 A.D.

Furthermore, another style of the mihrabs appeared in Aleppo during this period and reflects the Ottoman influences in this regard. This style represents in the mihrabs that were covered by pottery tiles such as the mihrab of al-Omari mosque which was renewed in 1276 A.H/ 1859 A.D (Othman, 1992), and a flat pottery mihrab in the eastern portico of the mehmendar mosque which was added during the Ottoman renewal works in 1323 A.H/ 1905 A.D (Abd al-Razik, 2015).

Besides the foreign styles that reflected the Ottoman influences, the local styles of the mihrabs continued in the religious buildings of Aleppo during this period and were even more prevalent than those foreign styles. The local mihrab, which spread before the Ottoman period composes of a simple niche devoid of decorations, surmounted by a simple cap with a pointed arch, and sometimes surrounded by two columns on its two sides (Fares, 1979). This local style of the mihrab did not limit to the buildings that were constructed according to the local styles but appeared also in the buildings of the Ottoman plan, which assert the local influences on these buildings.

Among the examples of the local mihrab in the buildings of the Ottoman plan, the main mihrab of the al-Khusrawiyyah madrasa 951 A.H/ 1544 A.D (pl. 16, a), where its cap devoid of stalactites although the madrasa was constructed on the Ottoman plan. This applied also to the mihrab of al-Othmaniyyah madrasa 1141 A.H/ 1730 A.D (pl. 16, b), and the mihrab of al-Ikhlasiyyah Tekyia 1044 A.H/ 1634 A.D. The local mihrab appeared also in al-Sha baniyyah madrasa 1085 A.H/ 1674 A.D, the mihrab of al-Mashatiyyah mosque 1134 A.H/ 1722 A.D, the mihrab of al-Kawakibiyyah madrasa 1167 A.H/ 1753 A.D, the mihrab of al-Sayafiyyah madrasa 1249 A.H/ 1833 A.D, and the mihrab of alIsma iliyyah madrasa 1255 A.H/ 1839 A.D. 
The local and foreign influences on religious architecture in Aleppo during the Ottoman period

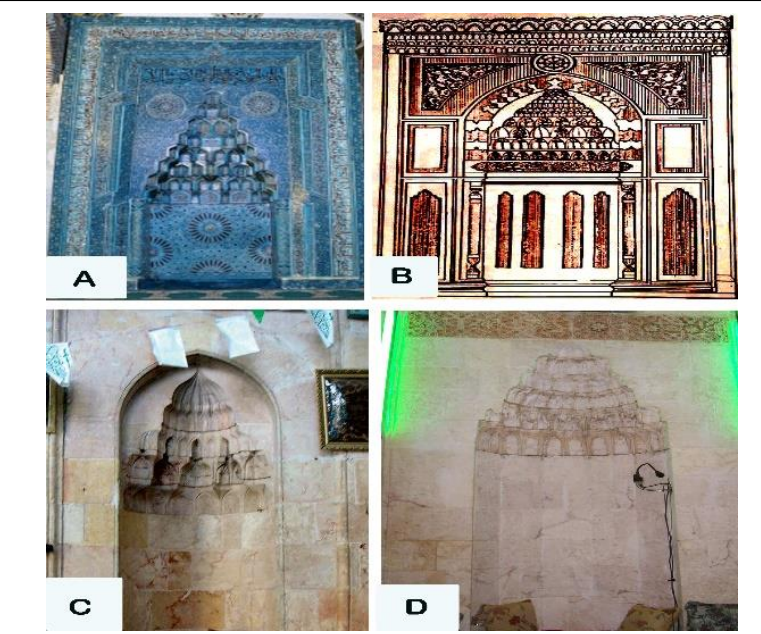

Pl. 15: Mihrabs in Seljuk and Ottoman style: (a) Ashraf Uğlu mosque 699 A.H/ 1298 A.D, Beyşehir (Atia, 2007, fig. 26). $\underline{(\text { b) }}$ al-'Adiliyyah 963 A.H/ 1555 A.D. (c) Aghajaq 973 A.H/ 1560 A.D. $\underline{\text { (d) }}$ Ibshir pasha 1063 A.H/ 1652 A.D, Aleppo. By the author.

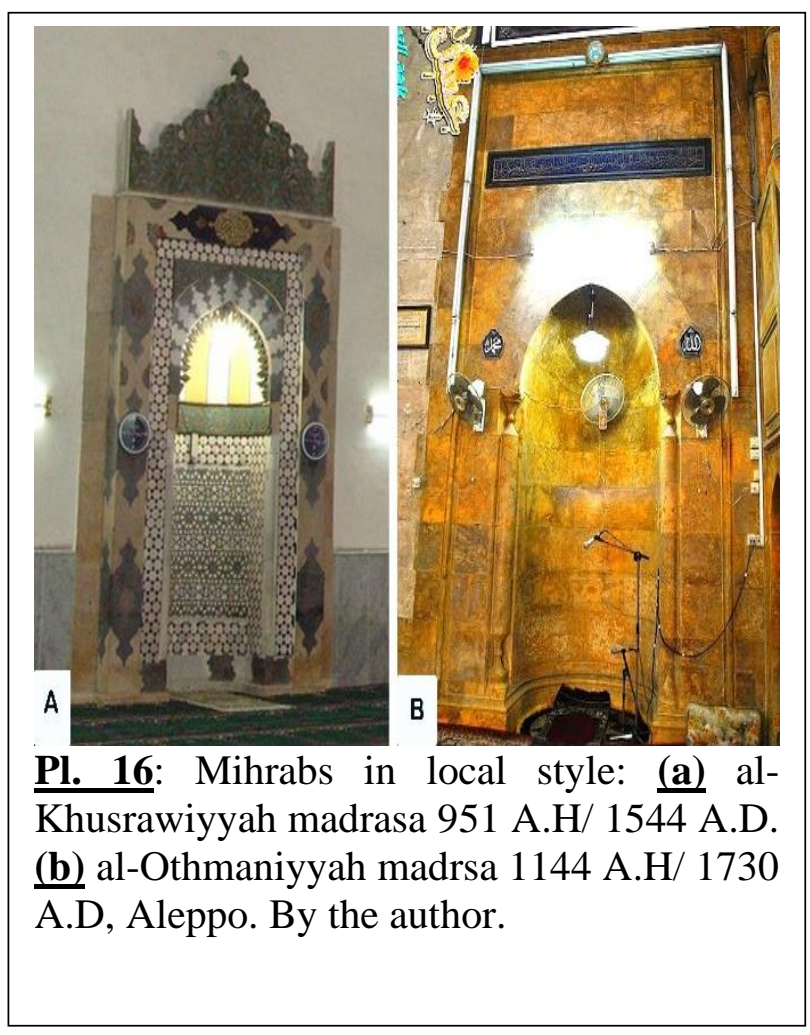

The influence of the local mihrabs was not limit to their general shape but rather extended to their multiplicity within the same building as well as in their locations. The buildings of the earlier periods characterized by the multiplicity of their mihrabs and the wall of the sanctuary included more than one mihrab as usual such as Mehmendar mosque $8^{\text {th }}$ A.H/ $14^{\text {th }}$ A.D century, al-Karimiyyah mosque 662 A.H/ 1264 A.D, Minkali Bugha mosque 768 A.H/ 1367 A.D, and Ashiqtumur mosque 773 A.H/ 1372 A.D (Abd al-Razik, 2020). This phenomenon affected the buildings of the Ottoman period such as al-Khusrawiyyah madrasa 951 A.H/ 1544 A.D which includes two mihrabs in the wall of its sanctuary in addition to the main one. This applied also to al- adiliyyah mosque 963 A.H/ 1555 A.D, and al-Bahramiyyah mosque 991 A.H/ 1583 A.D.

\subsection{The arches:}

The influence of the foreign Ottoman style on the arches as an architectural element was limited, where the majority of their examples were a continuation to the local styles. However, there are new types of arches that appeared in the religious buildings in Aleppo for the first time during this period such as the four-centers arch which is different from the traditional pointed arch and is considered one of the characterizes of Ottoman architecture in Aleppo (Othman, 1992). Also, the uses of this arch were varied as it used under the dome of al-Khusrawiyyah madrasa 951 A.H/ 1544 A.D, surmounted the windows of al-'adiliyyah mosque 963 A.H/ 1555 A.D, and surmounted the mihrabs such as the mihrab of al-Khusrawiyyah madras (pl. 16, a) and alMashatiyyah mosque 1134 A.H/ 1722 A.D. 
Among the type of arches that spread in Aleppo during this period, the curved arch which widely spread in the Ottoman architecture in the city. Although the curved arch is considered one of the characterizes of Ottoman architecture, nevertheless it appeared in an earlier period in Egyptian architecture since the $5^{\text {th }}$ A.H/ $11^{\text {th }}$ A.D century in the Fatimid gates of Cairo. The most famous function of the curved arch in the Ottoman buildings in Aleppo, using in surmounting the windows and the main entrances, in contrast to the earlier periods in which the straight arch was common. The curved arch appeared in many examples during the Ottoman period such as the entrance of alKhusrawiyyah madrasa 951 A.H/ 1544 A.D (pl. 6, a), the entrance of al-'adiliyyah mosque 963 A.H/ 1555 A.D (pl. 6, b), the entrance of al-Bahramiyyah mosque 991 A.H/ 1583 A.D (pl. 7, a), the entrance of al-Sha baniyyah madrasa 1085 A.H/ 1674 A.D, the entrance of al-Othmaniyyah madrasa 1144 A.H/ 1730 A.D, the entrance of al-Hajj Musa mosque 1177 A.H/ 1763 A.D, the entrance of al-Kamaliyyah mosque 1187 A.H/ 1773 A.D (pl. 8, b) and the entrance of Salih al-Hal mosque 1317 A.H/ 1899 A.D.

Furthermore, the local styles have a great effect on the continuation of the local arches that spread before the Ottoman period such as the traditional pointed arch, which widely spread in the Ottoman religious buildings. Among the local influences in the field of the arches, the straight arch that appeared in some examples above the main entrance such as the entrance of al-Balat al-Fawqani mosque 1061 A.H/ 1650 A.D, the entrance of Ibshir Pasha mosque 1063 A.H/ 1652 A.D, and the entrance of al-Barraqiyyah Teykia 1237 A.H/ 1822 A.D.

In addition to the preceding, the arch of the overlapping-voussoirs that spread in Aleppo in the earlier periods continued with the same features during the Ottoman period, which asserts the local influences on the Ottoman buildings. The arch of the overlapping-voussoirs appeared in Aleppo since the Ayyubid period in the mihrab of alShazbakhtiyyah madrasa 589 A.H/ 1193 A.D (Ismail, 2013), the mihrab of al-Sultaniyyah madrasa 620 A.H/ 1223 A.D (pl. 17, a), the mihrab of al-Firdus madrasa 633 A.H/ 1236 A.D and appeared also in the Mamluk buildings such as the mihrab of Minkali Bugha mosque 768 A.H/ 1366 A.D (Morsy, 2003) (pl. 17, b). The local influence of this arch continued in the Ottoman buildings where it appeared in the mihrab of alBahramiyyah mosque 991 A.H/ 1583 A.D (pl. 17, c), which was built according to the

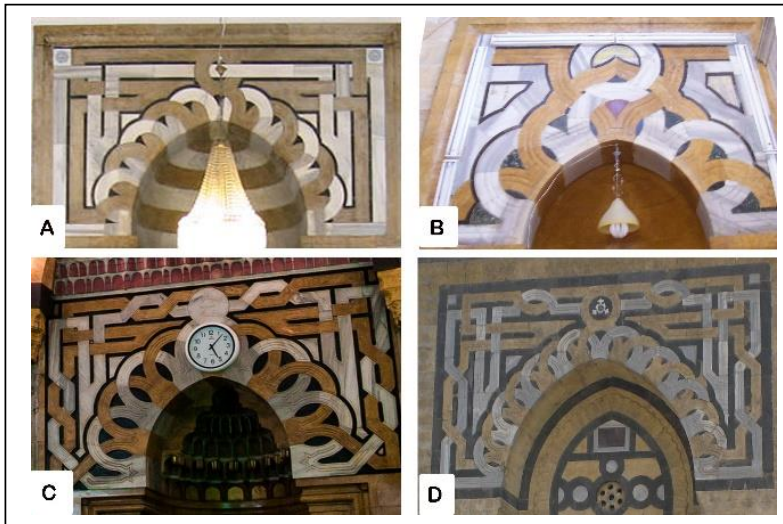

Pl. 17: The arch of overlapping voussiors: (a) the mihrab of al-Zahiriyyah madrasa 620 A.H/ 1223 A.D. (b) the mihrab of Minkali Bugha mosque 768 A.H/ 1366 A.D (c) the mihrab of al-Bahramiyyah mosque 991 A.H/ 1583 A.D $\underline{\text { (d) })}$ the entrance of the sanctuary of the great Umayyad mosque renewed 1039 A.H/ 1629 A.D, Aleppo. By the author.

Ottoman style with a stalactite cap but at the same time, its arch composes of 
overlapping-voussoirs according to the local style with the same features of the earlier periods (Abd al-Razik, 2017).

Among the examples of the arch of the overlapping-voussoirs during the Ottoman period, the arch that surmounts the entrance of al-Hallawiyah madrasa, which was renewed in 1315 A.H/ 1897 A.D (al-Jasir, 2000). Among these also, the arch that surmounts the entrance of the sanctuary of the great Umayyad mosque, which was renewed during the Ottoman period in 1039 A.H/ 1629 A.D (Gaube, 1978) (pl. 17, d). These examples were made in a shape that is completely identical to those examples that date back to the earlier periods, which assert the local influences in this regard.

\subsection{The minbars:}

The religious buildings that were constructed in the city of Aleppo during the Ottoman period included examples of the minbars that followed the local style. They depended on wood, stone, and marble as raw materials, decorated with floral and geometrical decorations, and sometimes included inscriptions. The majority of the local minbars depended on a small dome with a pointed arch as a cap surmounted them. This local style of the minbars appeared before the Ottoman period in many examples such as al-Tonbugha mosque 718 A.H/ 1318 A.D, and al-Atrush mosque 812 A.H/ 1409 A.D.

The local style of the minbar continued to the religious building of the Ottoman period in the city such as the minbar of Ibshir pasha 1063 A.H/ 1652 A.D. It appeared also in al-Othmaniyyah madrasa 1141 A.H/ 1730 A.D which include a stone minbar beside its main mihrab and followed the local style that it has a cap in a shape of a small copula with a pointed sector (pl. 18, a).

Beside the local style of the minbar, there are a new style appeared in Aleppo during the Ottoman period and reflects the Ottoman influences of the minbar of the Ottoman mosque in Istanbul. This style characterizes by its elegant shape and its conical cap. This new style that reflects the Ottoman influences appeared for the first time in al-Khusrawiyyah madrasa 951 A.H/ 1544 A.D (pl. 18, b). Then, it appeared in al'adiliyyah mosque 963 A.H/ 1555 A.D (pl. 18 , c), and al-Bahramiyyah mosque 991

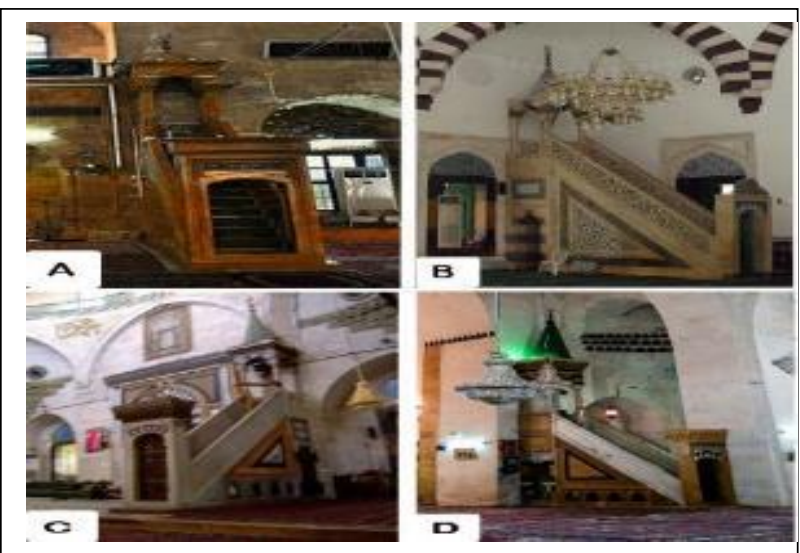

Pl. 18: Examples of the minbars: $\underline{\text { (a) }}$ the minbar of al-Othmaniyyah madrasa 1141 A.H/ 1730 A.D. (b) the minbar of alKhusrawiyyah madrasa 951 A.H/ 1544 A.D (c) the minbar of al- adiliyyah mosque 963 A.H/ 1555 A.D (d) the minbar of alBahramiyyah mosque 991 A.H/ 1583 A.D, Aleppo. By the author. A.H/ 1583 A.D (pl. 18, d). 


\section{The Turkish inscriptions:}

Among the foreign influences on the religious architecture of Aleppo during the Ottoman period the inscriptions that were recorded on those buildings by Turkish language to reflect a pure Ottoman influence on them during this period. These inscriptions varied in their content that many of them are foundation inscriptions such as the inscription that is located above the entrance of the sanctuary of al- adiliyyah mosque 963 A.H/ 1555 A.D, it proved that the mosque was constructed by Mohamed pasha Duqakin but at the same time it was written after the construction as it dates back to 974 A.H/ 1566 A.D (Othman, 2010) (pl. 19, a). Among the foundation inscriptions that were recorded by Turkish language, the inscription that is located above the entrance of Ibshir pasha mosque $1063 \mathrm{~A} . \mathrm{H} / 1652 \mathrm{~A} . \mathrm{D}$, it include phrases that praise to the constructor and proves the foundation date of the mosque (Othman, 2010), (pl. 19, b).

The religious architecture of Aleppo during the Ottoman period includes also many inscriptions that prove the renewal works that were occurred in these buildings during this period. Among these, the inscription that is located above the interior façade of the entrance of alMawlawiyah tekyia 1176 A.H/ 1762 A.D, it texted on that the buildings was destroyed after an earthquake that occurred in Aleppo and renewed again by Wahid pasha in 1240 A.H/ 1824 A.D (pl. 19, c).

The most important Ottoman influences in the field of the inscriptions on the religious building during this period, the Ottoman Tughraa which spread

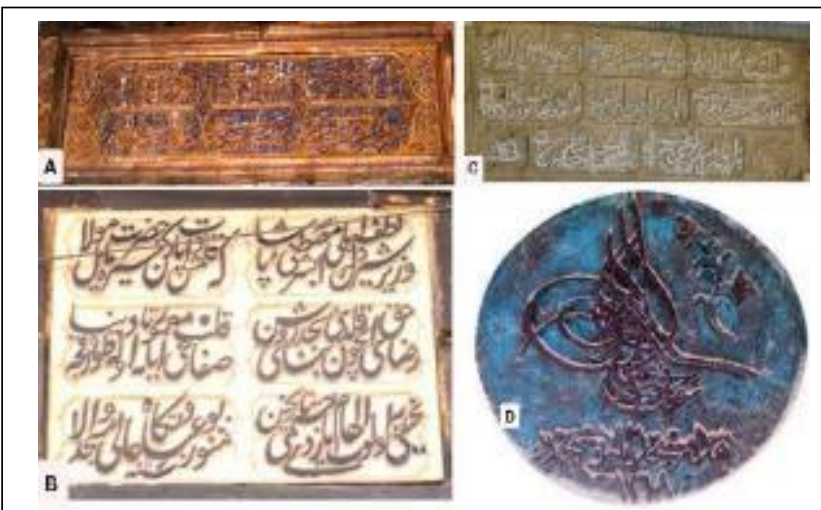

Pl. 19: Examples of the Turkish inscriptions: (a) al- adiliyyah mosque 963 A.H/ 1555 A.D (b) Ibshir pasha mosque 1063 A.H/ 1652 A.D $\underline{\underline{(c)}}$ al-Mawlawiyyah tekyia 1176 A.H/ 1762 A.D (d) the mosque of al-Abraj 1313 A.H/ 1895 A.D, Aleppo. By the author.

in the buildings that constructed and renewed during the Ottoman rule especially the Tughraa of al-Sultan Abd al-Hamid II. Among these examples, the Tughraa of al-Sultan Abd al-Hamid II above the entrance of the sanctuary of the Hajj Musa mosque 1176 A.H/ 1762 A.D. Among these also an example located above the entrance of the mosque of alAbraj 1313 A.H/ 1895 A.D which includes al-Sultan's name and a renewal date 1318 A.H/ 1900 A.D (pl. 19, d). There is also another example located above the mihrab of Salih al-Hal mosque 1317 A.H/ 1910 A.D by the name of the same Sultan.

\section{The architectural treatments:}

The architect resorted to using some architectural treatments in the religious buildings of Aleppo to reconcile between the space that was allocated to these buildings and the borders of the street that overlooks them, or to reconcile them with the surrounding buildings. By following the methods adopted by the architect in such architectural treatments, it is found that the local influences were achieved in this aspect, 
as some of these treatments used by the architect in earlier periods and in the same method continued during the Ottoman era.

An example of these architectural treatments is the architect's resort to making a deviation along one of the building's facades to reconcile and respect the street that the façade overlooks. This architectural treatment can be noticed in the plan of alSultaniyyah madrasa 620 A.H/ 1223 A.D in its southern façade, which was made in a deviation shape to the eastern side to respect the extend of the street that it overlooks (fig. 10). This applied also to the western façade of mehmendar mosque $8^{\text {th }}$ A.H/ $14^{\text {th }}$ A.D century (Abd al-Razik, 2015) and the western façade of Ogelbek mosque 881 A.H/ 1477 A.D (Abd al-Razik, 2019). This architectural treatment continued during the Ottoman period in the same manner in al-Khusrawiyyah madrasa 951 A.H/ 1544 A.D, as the northern part of its western façade was deviated to respect the extend of the street that it overlooks (fig. 3).

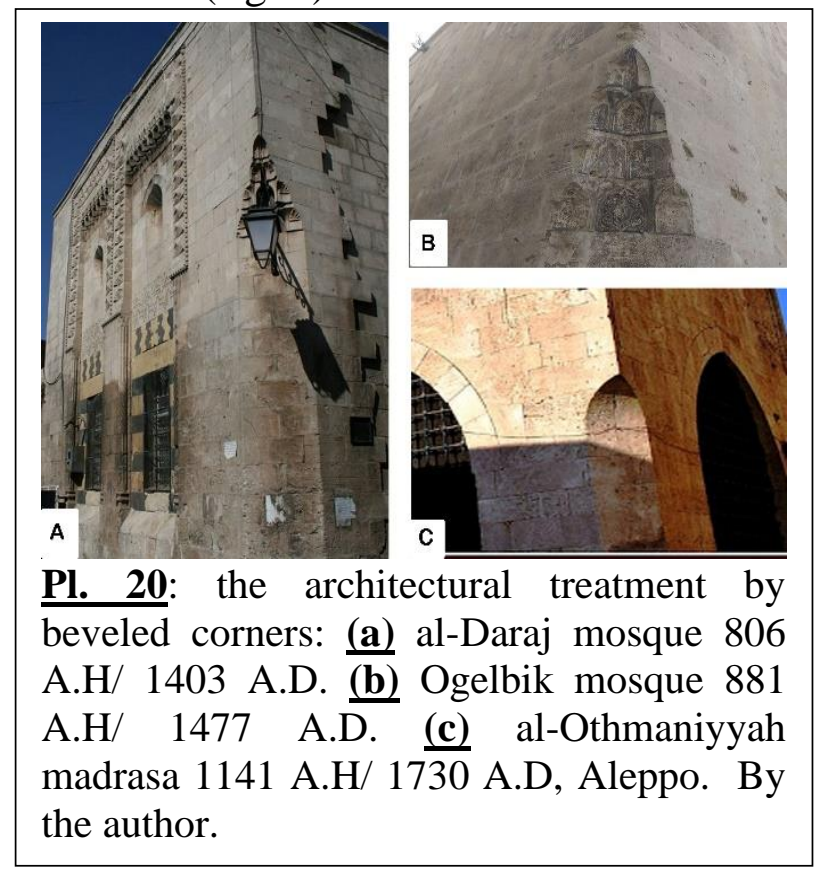

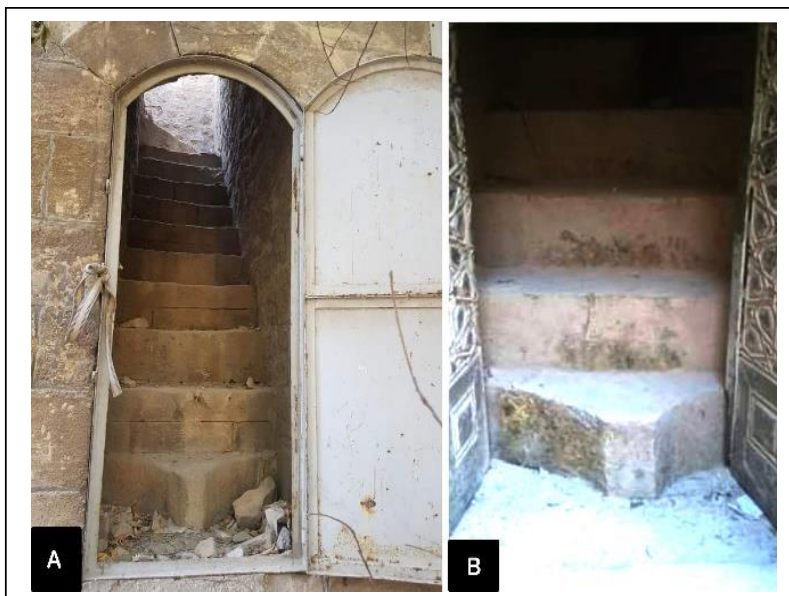

Pl. 21: the architectural treatment by the triangle stairs: (a) Mehmendar mosque $8^{\text {th }} /$ $14^{\text {th }}$ century. (b) al-'Adiliyyah mosque 963 A.H/ 1555 A.D, Aleppo. By the author.

Sometimes, the architect resorted to making a deviation in the sanctuary to reconcile the borders of the external street and the Qibla direction so the sanctuary composes of a deviated rectangular. This occurred in the sanctuary of al-Ansariyyah madrasa, which is called al-Alamy turbah 604 A.H/ 1207 A.D (al-Jasir, 2000). This architectural treatment appeared during the Ottoman period with the same style in the sanctuary of Ibshir pasha mosque 1063 A.H/ 1653 A.D (fig. 13), which asserts the local influences in this regard.

Among the architectural treatments that were used in the earlier periods and continued during the Ottoman era, the treatment of the building's corners especially those overlook the street corners to protect the corner of the building itself and respect the borders of the street. This treatment is carried out by forming the corner in the shape of a built-in column or in a shape of a beveled corner that sometimes surmount by stalactites. 
It appeared for the first time in Aleppo in al-Shihabiyyah mosque 544 A.H/ 1150 A.D (Ismail, 2013), the mosque of al-Daraj 806 A.H/ 1403 A.D (pl. 20, a), and Ogelbek mosque 881 A.H/ 1477 A.D (pl. 20, b) (Abd al-Razik, 2019). It moved to the religious buildings of the Ottoman period with the same style as appeared in the southeastern corner of Ibshir Pasha mosque 1063 A.H/ 1653 A.D, and al-Othmaniyyah madrasa 1144 A.H/ 1730 A.D (pl. 20, c).

One of the striking architectural treatments is the idea of the triangle stairs behind the doors especially those lead to the minarets. The architect used this idea in the corridor that includes the staircase which leads to the minaret, this corridor is usually closed by a door behind it directly the mentioned staircase. So, the architect resorts to form the first stair in a triangle shape to leave a space for the door's round. This treatment appeared in the staircase that leads to the minaret of mehmendar mosque $8^{\text {th }}$ A.H/ $14^{\text {th }}$ A.D century (pl. 21, a) and repeated in the same manner in the staircase that leads to the minaret of al'Adiliyyah mosque 963 A.H/ 1555 A.D (pl. 21, b) which assert of replacing the influences among the earlier and the Ottoman periods.

\section{Conclusion:}

This paper is considered the first detailed study to discuss the local and foreign influences on the religious architecture that were constructed in Aleppo during the Ottoman period. Firstly, the paper showed that the city of Aleppo is one of the provinces of the Ottoman Empire that was most affected by the new Ottoman style in the field of architecture. As for the architectural plans, the paper referred that the plans of the religious buildings of this period included new styles that were not previously known. At the time, it referred that these new styles included the most prominent examples of the religious buildings of the city, while the largest number of these buildings were constructed according to the local styles even though they were inferior to those built on the new Ottoman styles. Moreover, the paper proved that in addition to the new ottoman and local plans, a new style appeared during this period combines the Ottoman and local style in one plan. Regarding the architectural elements, the paper indicated that the religious buildings of this period included new styles of the architectural elements that were affected by the Ottoman style or the styles of other Islamic countries, whereas the majority of their examples were built according to the local styles. Furthermore, the paper proved that some of the architectural elements that were executed according to the Ottoman style were also influenced by the local styles, as the architect executed them in Ottoman style with local features. Finally, the paper proved the local influences in the field of the architectural treatments that were applied during the Ottoman period. 


\section{The local and foreign influences on religious architecture in Aleppo during the}

Ottoman period

\section{End notes:}

${ }^{1}$ This mosque and madrasa is attributed to Amir Khusro pasha the deputy of Aleppo in 937-940 A.H/ 1531-1534 A.D, it is considered one of the most important and first buildings that were constructed according to the Ottoman style. Many endowments were endowed on this mosque by its constructor around its area and in other districts in the city, for more detail: (al-Ghuzzi, 1999), (al-Tabbakh, 1925), (Talas, 1956), (Rifa 'i, 2013).

${ }^{2}$ This mosque was constructed by Mohamed pasha Duqakin Zadah the deputy of Aleppo in 958960 A.H/ 1551-1553 A.D, and the deputy of Cairo in 960-963 A.H/ 1553-1555 A.D. the mosque is called by this name because of its location beside the judgment house dar al-'adl. It is considered on of the biggest mosques in the city of Aleppo, it has a great waqf that includes four souqs includes 157 shops in addition to three khans, for more detail: (al-Ghuzzi, 1999), (alTabbakh, 1925), (Talas, 1956), (Gaube \& wirth 1984), (Raymond, 1998), (Morsy, 2015).

3 The mosque of Bahram pasha is considered one of the biggest mosques of Aleppo that was constructed during the $10^{\text {th }}$ A.H/ $16^{\text {th }}$ A.D century according to the Ottoman style in the city of Aleppo. Also, it is considered with its endowments around its area and in other districts in Aleppo a complete architectural complex, for more detail: (al-Ghuzzi, 1999), (al-Tabbakh, 1925), (Talas, 1956), (Gaube \& wirth 1984), (Raymond, 1998), (Kaçan, 2010), (Abd al-Razik, 2017).

4 As customary in the mosques of the Ottoman style, the original dome of the mosque of alBahramiyyah rests on the sidewalls of the sanctuary but this dome was destroyed because of the earthquake that occurred in 1237 A.H/ 1822 A.D. The dome was still destroyed until it was rebuilt again in 1276 A.H/ 1860 A.D and changed to rest on four pillars instead of the sidewalls of the sanctuary. (al-Tabbakh, 1925), (Heretani, 2006).

${ }^{5}$ This architectural complex constructed by Ibshir pasha the deputy of Aleppo in al-Jadidah district in 1063 A.H/ 1653 A.D. the complex is considered one of the biggest building that constructed in the city during this period that it includes a mosque and many endowments included in the same construction (David \& Heretani, 1982).

${ }^{6}$ Al-Othmaniyyah madrasa is called also al-Rida'iah madrasa; it is one of the city's monuments that was constructed according to the Ottoman style. It is located in al-Farafrah district and was constructed by Othman pasha Ibn Abd al-Rahman pasha al-Durki, for more detail: (al-Ghuzzi, 1999), (al-Tabbakh, 1925), (Talas, 1956).

${ }^{7}$ This mosque is located in al-Jallum district. It was constructed by Yahia Ibn al-Hajj Musa alRayhawi Ibn Ahmed al-Nahlawi who endowed a great waqf on it. The mosque is called by this name because it includes two stairs; the first leads to the ground floor, and the second leads upstairs.

8 The Architectural features of this mosque was changed because of the restoration works that occurred in 1183 A.H/ 1770 A.D but the original plan was compatible with the Ottoman style as it composes of a square sanctuary roofed by a dome in addition to an aisle fronted the sanctuary (Othman, 1992).

9 Regarding the buildings that were constructed according to the local styles, they are a continuation of these inherited styles but it is not mean that they did not influence by the new Ottoman styles as they included some foreign influence in their architectural details.

10 This external aisle or portico fronted the religious architecture widely spread in Ottoman Turkey, which was inherited from Seljuk architecture. For more detail about this regard: (Zaki, 2017). 
11 This style of these entrances is considered one of the influences of the Seljuk in Ottoman architecture. It appeared in the majority of its examples such as Mihr-mah sultan mosque in Istanbul 950-954 A.H/ 1544-1548 A.D, the entrance of the sanctuary in the mosque of Shah-zada Moahmed in Istanbul 950-955 A.H/ 1543-1548 A.D, the entrance of the mosque of Ali pasha in Tuqat 980 A.H/ 1572 A.D, the entrance of Msīh Pasha mosque in Istanbul 994 A.H/ 1585 A.D, and the mosque of Sultan Ahmed in Istanbul 1012-1017 A.H/ 1603-1617 A.D (Goodwin, 2003), (al-Banna, 2018).

${ }_{12}$ Generally, this style of entrance began to appear in Abbasid architecture in the $3^{\text {rd }}$ A.H/ $9^{\text {th }}$ A.D century, its first example was in al-Mu tasim palace in Samarra. Then, it appeared in Syria during the Ayyubid period. After that, it appeared in Egypt for the first time in Alin Aq alHusami palace 793 A.H/ 1293 A.D and Zain al-Din Yousif zawiya 797 A.H/ 1297 A.D (Creswell, 1959), (Abo al-Futuh, 1975).

${ }^{13}$ Firstly, the triple-arch or al-'aqd al-mada'ini used as transition zones to the domes of the Iranian mosques since the first trimester of the $5^{\text {th }}$ A.H/ $11^{\text {th }}$ A.D century. Then, its influences moved to the Fatimid architecture in Egypt in the last trimester of the same century and were used as transition zones for the Fatimid domes. After that, it developed to use in the entrances for the first time in Aleppo in entrance of al-maqdamiyyah madrasa 564 A.H/ 1168 A.D. Hence, the origin of this arch is Iranian, and using it for surmounting the entrances is a Syrian influence which moved to Egypt to use for the first time in the entrance of the minaret of Salar and Sinjar Khanqah 703 A.H/ 1303 A.D and above the eastern entrance of the mosque of al-Nasir Mohamed inside the citadel 735 A.H/ 1334 A.D. Finally, it was widely spread in Mamluk and Ottoman architecture. (Houtcoeur \& Wiet, 1932), (Najib, 2013), (Hamid, 2018).

${ }^{14}$ The common style of the minarets in Aleppo before the Mamluk period depended on the square shape, the most famous and the first example of this shape is the minaret of the great Umayyad mosque 483 A.H/ 1090 A.D, the minaret of the mosque of al-Dabbagha al- 'atiqah $7^{\text {th }}$ A.H/ $13^{\text {th }}$ A.D century, and the minaret of the great mosque inside the citadel 610 A.H/ 1213 A.D. By the beginning of the Mamluk period, the octagonal shaft became the common shape instead of the square shaft which was an Egyptian influence on Aleppo's minarets such as the minaret of al-Krimiyyah mosque, the minaret of al-Nasiriyyah madrasa, and the minaret of alHaddadin mosque. Another style that appeared in the same period depending on the cylindrical shape which was an influence that came from the eastern Islamic worlds such as the minaret of Mihmendar mosque $8^{\text {th }}$ A.H/ $14^{\text {th }}$ A.D century, and the minaret of al-Rumi mosque 769 A.H/ 1367 A.D. Moreover, the symbolic minaret style or the short minaret style such as the minaret of the mosque of Othman Ibn Ogelbek 881 A.H/ 1476 A.D (Abd al-Razik, 2014). 


\section{The local and foreign influences on religious architecture in Aleppo during the}

Ottoman period

\section{References:}

- Abd al-Razik, Mansour, 2014, al-turuz al-mi mariyyah lil-ma'zin al-baqiyyah bi-madinat halap, Historical events, vol. 20, pp. 299-382.

- Abd al-Razik, M, 2015, Mehmendar mosque in Aleppo, architectural archaeological study, Egyptian journal of archaeological and restoration studies, vol. 5, issue 2, pp. 145-158.

- Abd al-Razik, M., 2016, Al-Rumi "Menkali Bogha" mosque in Aleppo: Architectural and archaeological study, Egyptian journal of archaeological and restoration studies, vol.6, issue2, pp.133-149.

- Abd al-Razik, Mansour, 2017, Mosque of Bahram Pasha and its endowments in Aleppo (Syria), scientific culture, vol.3, issue 1, Greece, pp. 1-10.

- Abd al-Razik, M., 2019, Mosque of Othman ibn Oghelbek in Aleppo: An architectural and archaeological study, Egyptian Journal of archaeological and restoration study, vol.8, issue 1, pp. 79-95.

- Abd al-Razik, Mansour, 2020, al-Karimiyyah mosque in Aleppo, Syria: an architectural and archaeological study, SHEDET, vol. 7, pp. 201-230.

- Abo al-Futuh, Mohamed, 1975, madakhil al-'ama'ir al-mamlukiyyah bi-al-qahirah aldiniyyah wal-madaniyyah 648-784 A.H/ 1250-1382 A.D, master theses, faculty of archaeology, Cairo University.

- Al-Banna, Sameh, 2018, al-'anasir al-mi mariyyah w-al-zukhrufiyyah al-mamlukiyyah waathraha ala mthilatiha bi-al-asr al-othmani fi doa nmazij min misr wa turkia, journal of the general union of Arab archaeologists, vol. 19, pp. 1015-1055.

- Al-Afandi, Rami, 2017, The legacy of Aleppien Ottoman houses, international journal of heritage architecture, vol. 1, No. 3, pp. 388-400.

- Al-Haddad, Mhamed Hamza, 1998, mawsu it al- 'imara al-islamiyyah fi misr min al-fath alothmani hatta asr Mohamed ali 923-1265 A.H/ 1517-1848 A.D, maktabit zahraa al-sharq, Cairo.

- Al-Haddad, Mohamed Hamza, 2014, al-mojmal fi-al-athar wal-hadarah al-Islamiyyah, $3^{\text {rd }}$ edition, maktabit Zahraa al-sharq, Cairo.

- Al-Ghuzzi, Kamil, 1999, nahr al-Zahab fi tarikh halap, al-matb ah al-maruniyyah, Aleppo.

- Al-Jasir, Lamyaa, 2000, madaris halap al-athriyyah, dar al-Radwan, Aleppo.

- Al-Shinnawy, Abd al-Aziz Mohamed, 1980, al-dawlah al-othmaniyyah dawlah moftara 'aliha, maktabit al-anglo al-misriyyah, Cairo.

- Al-Tabbakh, Mohamed, 1925, a 'lam al-nobla' bi tarikh halap al-shahba', al-matb 'ah alilmiyyah, Aleppo.

- Atia, Abdallah, 2007, dirasat fi al-fan al-turky, maktabit al-nahdah al-misriyyah, Cairo.

- Atia, Abdallah, 2007, jami ashraf ughlu bi-madinat beyshar, dirasah athariyyah mi 'mariyyah, journal of faculty of art, al-Mansura university, vol. 41, pp. 364-275.

- Badr, Mona, 2002, athar al-hadarah al-sijukiyyah fi diwal sharq al-'alam al-islami ala alhadaratin al-ayyubiyyah wa-al-mamlukiyyah fi misr, maktabit zahraa al-sharq, Cairo.

- Billah, Khaiyrah, 2008, al-monsha'at al-diniyyah fi al-gaza ir khilal al-asr al-othmani, PhD thesis, Archaeology institute, Algeria University.

- Bloom, Jonathan, 1989, Minaret, symbol of Islam, Oxford university press, Oxford.

- Creswell, K.A. C, 1959, The Muslim architecture of Egypt II, Ayyubid and early Bahrite Mamluk, Clarendon press, Oxford. 
- David, Jan Cloud\& Heritani, Mahmoud, 1982, Le waqf d'Ipšĭr paša a Alep (1063/ 1653) etude d'urbanism historique, Damas.

- David, Jan Cloud \& Heretani, Mahmoud, 2011, halap madinat al-tarikh, shu'a' lil-nashr, Aleppo.

- Enab, Mohamed, 2019, al-ta'thirat al-othmaniyyah ala al- imarah al-diniyyah fi al-yaman, Kan historical journal, vol. 44, pp. 19-40.

- Fares, Mohamed, 1979, maharib halap, turuziha al-faniyyah wal-mi'mariyyah, 'adiyat halap, vol. 4,5, pp. 123-180.

- Fares, Mohamed, 1997, The great Umayyad mosque of Aleppo, Dar al-Qalam al-arabi, Syria.

- Fekry, Ahmed, 1949, athar tunis al-islamiyyah, mu'assasit saidan lil-tiba'ah wal-nashr, Tunis.

- Freely, John, 2011, a history of Ottoman architecture, Wit press, London.

- Gaube, Heinz, 1978, Arabische inschriften aus Syrien, in commission bai Franz Steiner Verlag, Wiesbaden, Lebanon.

- Gaube, Heinz \& Wirth, Eugen, 1984, Aleppo : historische und geographische Beiträge zur baulichen Gestaltung, zur sozialen Organisation und zur wirtschaftlichen Dynamik einer vorderasiatischen Fernhandelsmetropole, , Wiesbaden.

- Goodwin, Godfrey, 2003, a history of Ottoman architecture, Thames and Hudson, London.

- Hamid, Heba, 2018, al-qiyam al-jamaliyah bi-madakhil al-asr al-mamluki al-bahri waljarkasi 648-923 A.H/ 1250-1517 A.D bi-madinati trabuls al-sham wal-qahira, dirasa muqaranah, journal of arts and architecture, vol. 13, pp. 592-622.

- Heretani, Mahmoud, 2006, halap wal-saltanah al-othmaniyyah, al-waqf wal-omran, shu'a' lil-nashr, Aleppo.

- Houtecoeur, L.\& Wiet, G., 1932, Les Mosquees du Caire, Paris.

- Ibn Iyas, Mohamed ibn Ahmed, 1982, bada' 'i al-zuhur fi waq'i $i$ al-dihur, $2^{\text {nd }}$ edition, alhai' ah al-misriyah lil-kitab, Cairo.

- Ismail, Asmaa Mohamed, 2013, al-ta'thirat al-suriyyah ala al-'ama'ir al-turkiyyah bi-bilad al-anadul, journal of the general union of Arab archaeologists, vol. 14, pp. 1-37.

- Kaçan, Meryem, 2010, Yüzyilda Halep'te Bir Osmanli Vakfi: Behram Paşa Külliyesi, Journal of Turkish cultural studies, vol. 22, Istanbul, pp. 1-26.

- Kafescioğlo, Çiğdem, , 1999, In the image of Rūm: Ottoman architecture patronage in sixteenth-century Aleppo and Damascus, Muqarnas, Vol. 16, pp.70-96.

- Moline, Judi, 1979, Saljuq minaret in Iran: structural developments, Kunst des orients, vol. 12, pp.95-102.

- Morsy, Mahmoud, 2003, dirasa 1-majmu'ah min al-'ama'ir al-islamiyyah al-diniyyah albaqiyyah bi-madinat dimashq min al-asr al-mamluki fi al-fatrah min al-nisf al-thani min alqarn 7 A.H/ 13 A.D wa-hatta mutasaf al-qarn 8 A.H/ 14 A.D, journal of the general union of Arab archaeologists, vol. 4, pp. 1007-1094.

- Morsy, Mahmoud, 2015, jami' al-'adilyyah bi-halap, dirash athariyah mi'maryyah, $6^{\text {th }}$ international conference, center of papyrus studies, Ain Shams University, Cairo, pp. 425456.

- Najib, Mohamed Mostafa, 2013, ta'sir al-arjul al-marwahiyyah ala al- 'iqud al-thulathiyyah al-madayniyyah bi madakhil munsh'at dawlati al-mamalik al-bahriyyah wal-jarkasiyyah 648-923 A.H/ 1250-1517 A.D, dirasah fi al-aqbiyah wal-ahqaq al-marwahiyyah bi-misrr wa al-sharq al-adna fi al-asr al-wasit, dar kitabat lil-nashr, Cairo, pp. 92-205. 


\section{The local and foreign influences on religious architecture in Aleppo during the}

Ottoman period

- Othman, Nagwa, 1992, al-handasa al-Insha'yah fi masajid halap, ma had al-turath al-ilmi, Aleppo.

- Othman, Nagwa, 2009, al-athar wal-awabid al-tarikhiyyah fi halap wa-killis wa-ghazi 'intab, Aleppo university press, Syria.

- Othman, Nagwa, 2010, dirasat naqa' ish al-'ahd al-othmani fi mohafazat halap - al-mabani wa-shwahid al-Qubur, al-maktabah al-waqfiyyah, Aleppo.

- Raymond, André, 1979, Les grand waqfs et l'organisation de l'espace urbain a Alep et au Caire a l'époque Ottomane (XVI-XVII siècles), Bulettin d'études orientals, Vol. 31, pp. 113128.

- Raymond, André, 1985, Grandes villes arabes à l'époque ottomane, Sindbad, Paris.

- Raymond, André, 1998, La ville arabe, Alep à l'époque ottoman (XVI - XVIII siècles), Damas.

- Rifa i, Mohamed, 2013, dirasah muqaranah bain jami ai al-khurawyyha, (halap, suria), walkhusrawiyyah (saraiyvo, al-busnah wal-harsak), dar nashri lil-nashr, Kuwait.

- Russell, Alex, 1794, The nature history of Aleppo, vol. 1, London.

- Safwat, Jamal, 2019, al-maharib al-athariyyah al-baqiyyah bi-'ama'ir al-anadul iban asr alimarat al-turkumaniyyah, dirasah fi doa namazij mukhtarah, journal of arts and humanities sciences, vol. 89, issue 1, pp. 266-278.

- Schacht, Josef, 1938, Ein archaischer minaret-type in Ägypten und Anatolien, Ars Islamica, vol. 5, No. 1, pp. 46-54.

- Tabbaa, Yasser, 1993, circle of power: Palace, citadel, and city in Ayyubid Aleppo, Ars orientalis, vol. 23, pp. 181-200.

- Wolsinger, Karl \& Watsiger, Karl, 1984, al-athar al-islamiyah fi madinat dimashq, Damascus.

- Zaki, Ahmed Mohamed, 2017, tatuwr shakl al-saqifah allati tataqaddam al-masajid alothmaniyyah- dirasah tahliliyah muqaranah, journal of the general union of Arab archaeologists, vol. 18, pp. 27-84.

- Zein al-'abidin, Mahmoud, 2010, taqwim tajrobat i'adit ta'hil ba 'd al-mabani al-tarikhiyyah al-othmaniyyah fi soria bi waza'if thqafiyyah, halat al-tawzif al-mathafi dirasah muqaranah, master thesis, Faculty of architectural engineering, Aleppo University. 